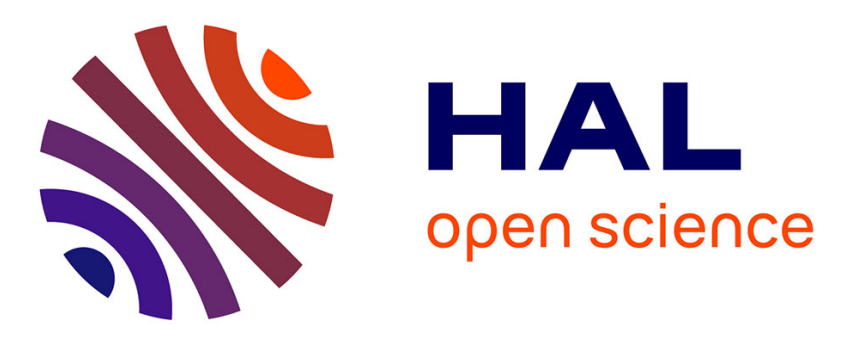

\title{
Clinical pharmacology of anti-angiogenic drugs in oncology
}

\author{
P. Gougis, J. Wassermann, J.P. P Spano, N. Keynan, C. Funck-Brentano, \\ Joe-elie Salem
}

\section{- To cite this version:}

P. Gougis, J. Wassermann, J.P. P Spano, N. Keynan, C. Funck-Brentano, et al.. Clinical pharmacology of anti-angiogenic drugs in oncology. Critical Reviews in Oncology/Hematology, 2017, 119, pp.75-93. 10.1016/j.critrevonc.2017.08.010 . hal-01662030

\section{HAL Id: hal-01662030 https://hal.sorbonne-universite.fr/hal-01662030}

Submitted on 12 Dec 2017

HAL is a multi-disciplinary open access archive for the deposit and dissemination of scientific research documents, whether they are published or not. The documents may come from teaching and research institutions in France or abroad, or from public or private research centers.
L'archive ouverte pluridisciplinaire HAL, est destinée au dépôt et à la diffusion de documents scientifiques de niveau recherche, publiés ou non, émanant des établissements d'enseignement et de recherche français ou étrangers, des laboratoires publics ou privés. 


\title{
Clinical pharmacology of anti-angiogenic drugs in oncology
}

\author{
P. Gougis ${ }^{\mathrm{a}, \mathrm{b}, \mathrm{c}, \mathrm{d}, \mathrm{e}, *}$, J. Wassermann ${ }^{\mathrm{e}}$, J.P. Spano ${ }^{\mathrm{e}, \mathrm{f}}$, N. Keynan ${ }^{\mathrm{b}}$, C. Funck-Brentano ${ }^{\mathrm{a}, \mathrm{b}, \mathrm{c}, \mathrm{d}}$, \\ J.E. Salem ${ }^{\mathrm{a}, \mathrm{b}, \mathrm{c}, \mathrm{d}}$ \\ a INSERM, CIC-1421 and UMR ICAN 1166, F-75013 Paris, France \\ b AP-HP, Pitié-Salpêtrière Hospital, Department of Pharmacology and CIC-1421, F-75013 Paris, France \\ c Sorbonne Universités, UPMC Univ Paris 06, Faculty of Medicine, F-75013 Paris, France \\ d Institute of Cardiometabolism and Nutrition (ICAN), F-75013 Paris, France \\ e Department of Medical Oncology, Groupe Hospitalier Pitié-Salpêtrière, University Pierre and Marie Curie (Paris VI), Institut Universitaire de Cancérologie, AP-HP, Paris, \\ France \\ ${ }_{\mathrm{f}}^{\mathrm{f}}$ Institut Pierre Louis d'Epidémiologie et de Santé Publique UMR S 1136, F-75013 Paris, France
}

Keywords:

Angiogenesis inhibitors

Neovascularization

Pharmacokinetics

Pharmacodynamics

Protein kinase inhibitors

Monoclonal antibodies

\begin{abstract}
A B S T R A C T
Abnormal vasculature proliferation is one of the so-called hallmarks of cancer. Angiogenesis inhibitor therapies are one of the major breakthroughs in cancer treatment in the last two decades. Two types of anti-angiogenics have been approved: monoclonal antibodies and derivatives, which are injected and target the extracellular part of a receptor, and protein kinase inhibitors, which are orally taken small molecules targeting the intra-cellular Adenosine Triphosphate -pocket of different kinases. They have become an important part of some tumors' treatment, both in monotherapy or in combination. In this review, we discuss the key pharmacological concepts and the major pitfalls of anti-angiogenic prescriptions. We also review the pharmacokinetic and pharmacodynamics profile of all approved anti-angiogenic protein kinase inhibitors and the potential role of surrogate markers and of therapeutic drug monitoring.
\end{abstract}

\section{Introduction}

Due to their enlarged and tortuous vessels, Hippocrates compared the cross section of tumors to crab claws. This observation would explain the name "carcinos" that he reportedly gave to this disease, which was later translated to the Latin word "cancer". Judah Folkman (Folkman et al., 1971) first provided an explanation for this vasculature, isolating what he called tumor angiogenesis factor. Falkman later proposed the inhibition of this angiogenesis factor as a treatment. Tumor cells need oxygen and nutrients to grow, and passive diffusion only happens at scales of less than a millimeter. Therefore, angiogenesis is a key process for a macroscopic tumor, one of the so called hallmarks of cancer (Hanahan and Weinberg, 2000). In the last couple of decades, the development of drugs targeting angiogenesis through inhibition of vascular endothelial growth factors (VEGF) and their receptors (VEGFR), led to an important change in the oncology field. Although they are targeting the same pathway, two different categories of drugs were developed: monoclonal antibodies (MABs) and their derivatives, which are $\operatorname{VEGF}(R)$-selective drugs administered intravenously and protein kinase inhibitors (PKIs), which are given orally (Figs. 1 and 2). PKIs are small molecules able to inhibit intracellular signal transduction. Kinases have a phosphorylation activity that regulates survival and proliferation of cellular processes. PKIs inhibit a wide spectrum of kinases and are not specific to VEGF and/or its receptor (Fig. 3). They have a different spectrum of action and adverse effects depending on the kinases they inhibit. PKIs have a narrow therapeutic index. Hence, knowing basic pharmacological concepts, drug interactions and management of PKIs toxicity improves the quality of patient care. In this review, we discuss the pharmacological particularities of angiogenesis inhibitors, their indications, and their clinical management.

\section{Clinical pharmacology}

\subsection{Pharmacological targets}

\subsubsection{VEGF/VEGFR pathway}

VEGF/VEGFR pathway is one of the major pathways in angiogenesis. The VEGF family consists of five members: VEGF-A, B, C, D and Placental Growth Factor (Roskoski, 2017). VEGFR family consists of three members: VEGFR-1 (i.e, Fms Like Tyrosine kinase FLT-1, gene name FLT1) and VEGFR-2 (i.e, Kinase insert Domain Receptor KDR,

\footnotetext{
* Corresponding author at: Centre d'Investigation Clinique Paris-Est, Groupe Hospitalier Pitié-Salpêtrière, University Pierre and Marie Curie (Paris VI), AP-HP, Paris, France.

E-mail address: paul.gougis@aphp.fr (P. Gougis).
} 


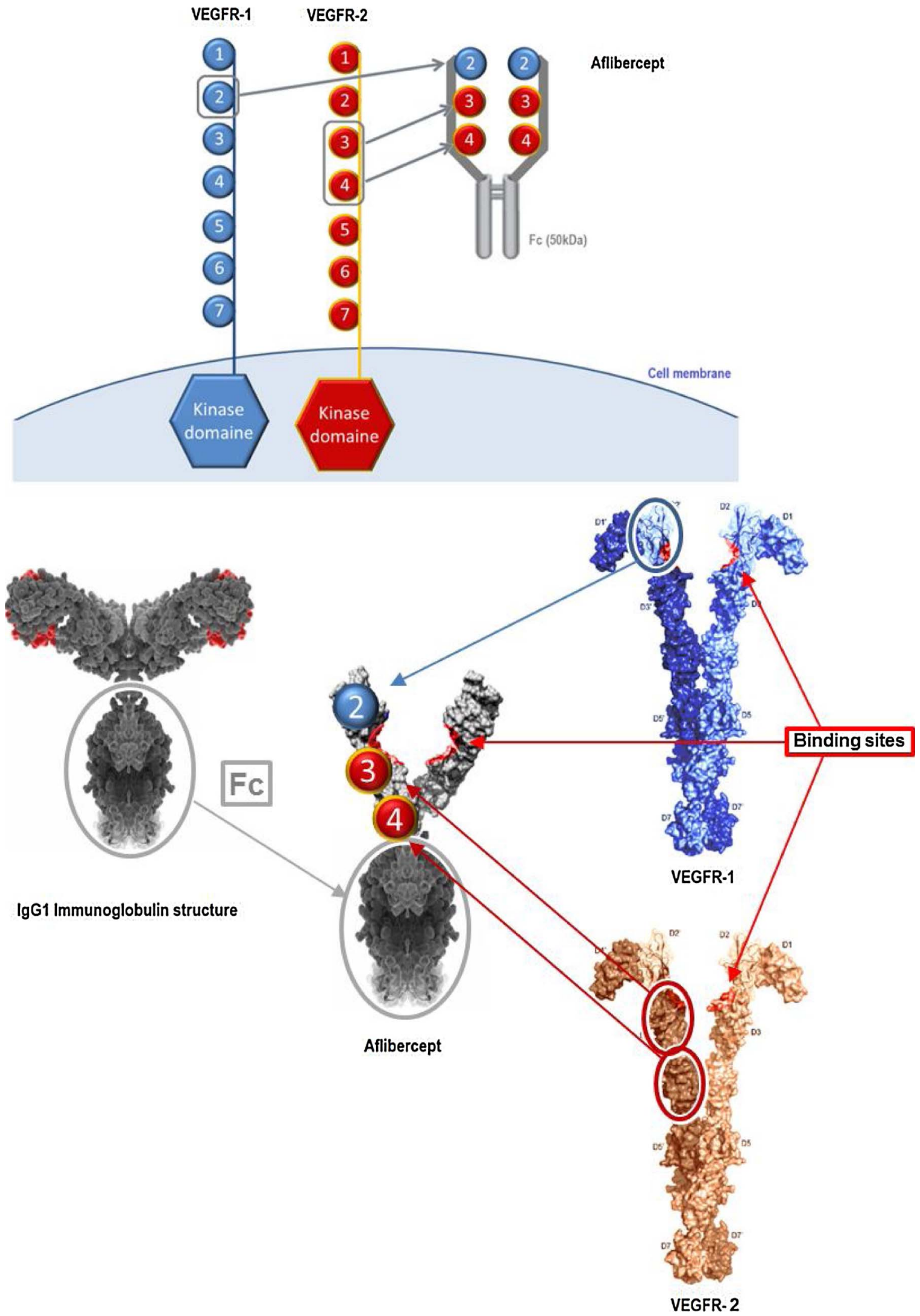

Fig. 1. Aflibercept structure. (For interpretation of the references to color in this figure legend, the reader is referred to the web version of this article.)

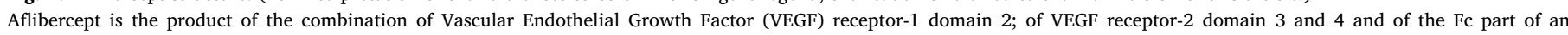
immunoglobulin. Aflibercept can bind with a high affinity to circulating VEGF-A, VEGF-B and PlGF which are both VEGFR-1 and VEGFR-2 ligands. Binding sites are shown in red. Abbreviations: Fc: crystallizable fragment; IgG: immunoglobulin type G; PlGF: Placental Growth Factor; VEGFR: vascular endothelial growth factor; 


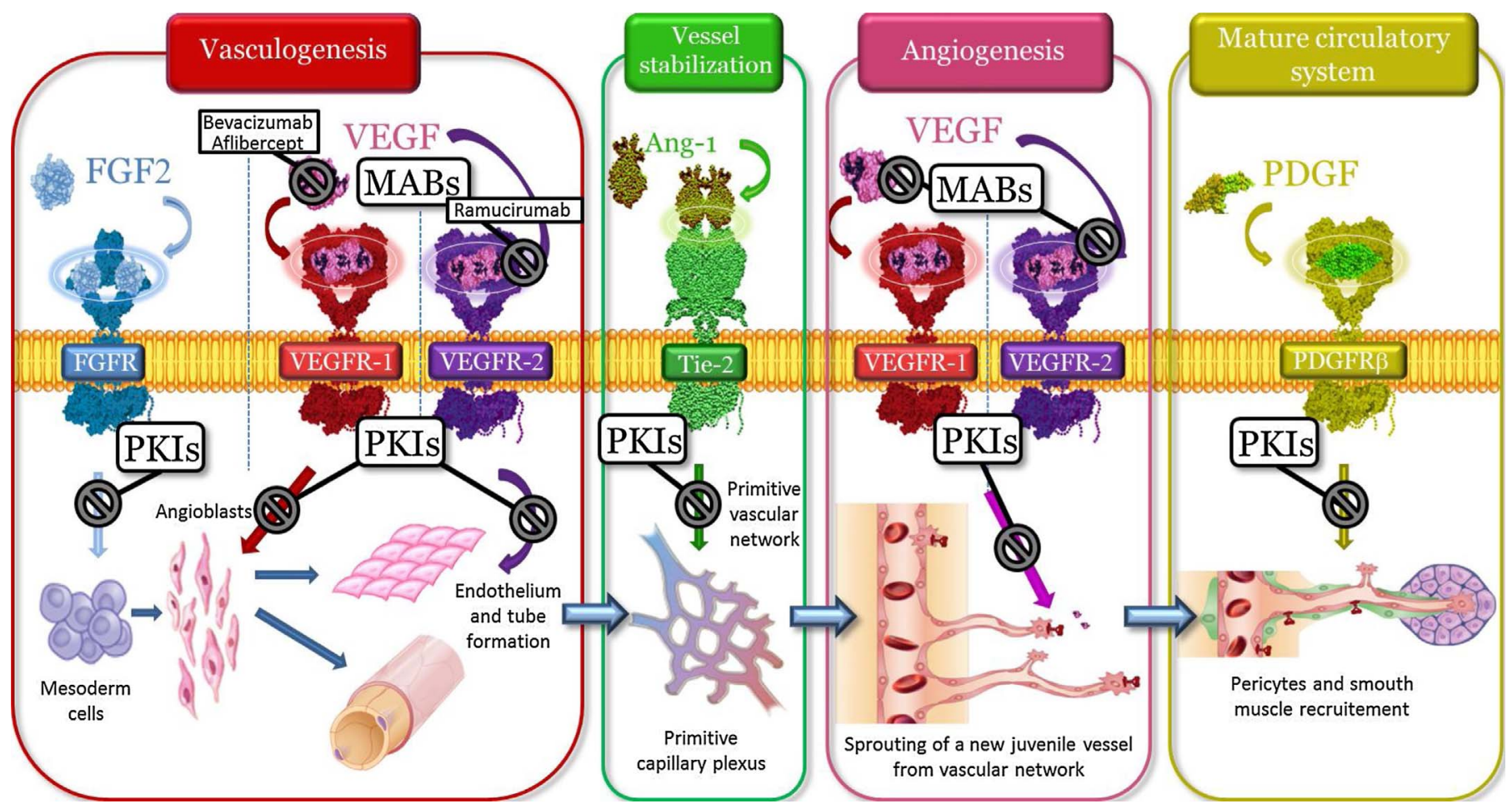

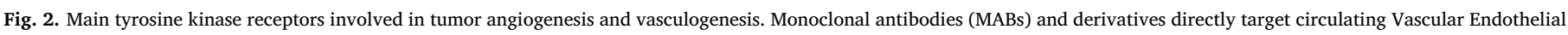

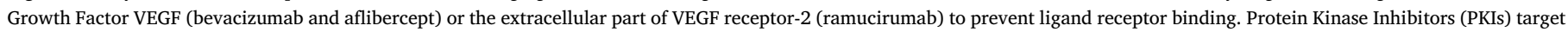
the intra-cellular parts of the tyrosine kinase receptor, with an affinity depending on the PKI spectrum of kinase inhibition (Fig. 3).

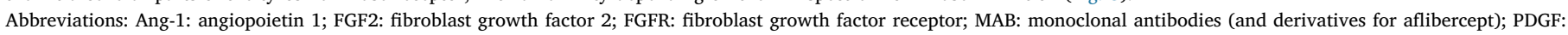

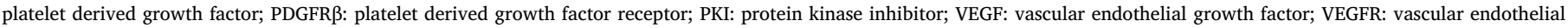
growth factor receptor;

gene name $K D R$ ) mainly involved in angiogenesis and vasculogenesis; VEGFR-3 (or Fms Like Tyrosine kinase FLT-4, gene name FLT4), mainly involved in lymphangiogenesis. VEGF-A, can either link to activate VEGFR-1, VEGFR-2 or neuropilin-1 (NRP1), the latter receptor also playing a role in both angiogenesis and vascular permeability (Shibuya, 2011). VEGF-A is a 45 kilo-Dalton (kDa) glycoprotein secreted by a large variety of human tumors. It is a mitogen protein, specific to endothelial cells, which is upregulated by hypoxia. It also triggers migration, differentiation, vascular permeability (Hicklin and Ellis, 2005) and mobilization of endothelial progenitor cells. VEGF receptors are transmembrane tyrosine kinase receptors: the ligand allows their dimerization that auto-phosphorylates and transduces the extracellular signal via either a mitogen activated protein (MAP) kinase or a phosphoinositide 3-kinase/mammalian target of rapamycin (PI3K/mToR) pathway to promote the proliferation and the survival of vascular endothelial cells (Fig. 2).

There are different splicing variants of VEGF. These multiple isoforms do not bind VEGFR-1, VEGFR-2 or NRP1 with the same affinity (Abou-Fayçal et al., 2017). Splice variants are known as VEGFxxx, where $\mathrm{xxx}$ is the total number of amino acids in the mature protein, and differ by their amino-acid sequences. Therefore, they might play a different role. VEGF-A(165)b for instance, has the same amino-acid sequence as VEGF-A(165) except for the last 6 ones. It has been demonstrated that VEGF-A(165)b attenuates signaling potential through VEGF receptor 2 (Cébe Suarez et al., 2006). VEGF-A isoforms also have different epitopes, and bevacizumab might have a different binding affinity to different isoforms. This might affect bevacizumab's binding through competitive binding. For example, VEGF-A(165) and VEGFA(165)b secretion produces a balance of antiangiogenic and proangiogenic actions in colorectal cancer (Varey et al., 2008). It regulates tumor growth rates and affects the sensitivity of tumors to bevacizumab by competitive binding. Of note, tumors might express different splicing variants of VEGF (Vempati et al., 2014)

2.1.2. Extracellular targeting by monoclonal antibodies and immunoglobulin derivatives

MABs have a molecular weight of around $150 \mathrm{kDa}$ and do not cross the cell membrane.

Bevacizumab is a recombinant humanized monoclonal antibody IgG1 targeting all isoforms of circulating VEGF-A.

Aflibercept was designed to have a broader spectrum of action than bevacizumab. It is a recombinant protein which is the fusion of both a VEGFR-1 and a VEGFR-2 extracellular domain portion to a crystallizable fragment $(\mathrm{Fc})$ of immunoglobulin (Fig. 1). Aflibercept is, therefore, able to "trap" circulating ligands of VEGFR-1 and VEGFR-2, namely VEGF-A, VEGF-B and Placental Growth factor (Holash et al., 2002; Papadopoulos et al., 2012).

Ramucirumab is a human monoclonal antibody IgG1 designed to target VEGFR-2. It is an antagonist and prevents the binding of all the extra-cellular ligands of VEGFR-2 to their target, which is responsible for the majority of angiogenesis processes.

\subsubsection{Intracellular targeting by PKIs}

PKIs are much smaller lipophilic molecules able to diffuse through different membranes (Adrian et al., 2007). PKIs are a group of drugs that inhibit the transduction of a biological pathway by blocking the enzyme activity of a tyrosine or a serine/threonine kinase. Most of the PKIs are poorly selective and inhibit a wide spectrum of other protein kinases (Uitdehaag et al., 2012). Their spectrum of inhibition, characterized in vitro by their half maximal inhibitory concentration (IC50) or constant of inhibition $\mathrm{Ki}$, is supposed to explain most of the differences in both activity and toxicity between PKIs (Davis et al., 2011). All approved anti-angiogenic (AA) PKIs target the VEGFR family, particularly VEGFR-1 and VEGFR-2. They also often inhibit members of the 


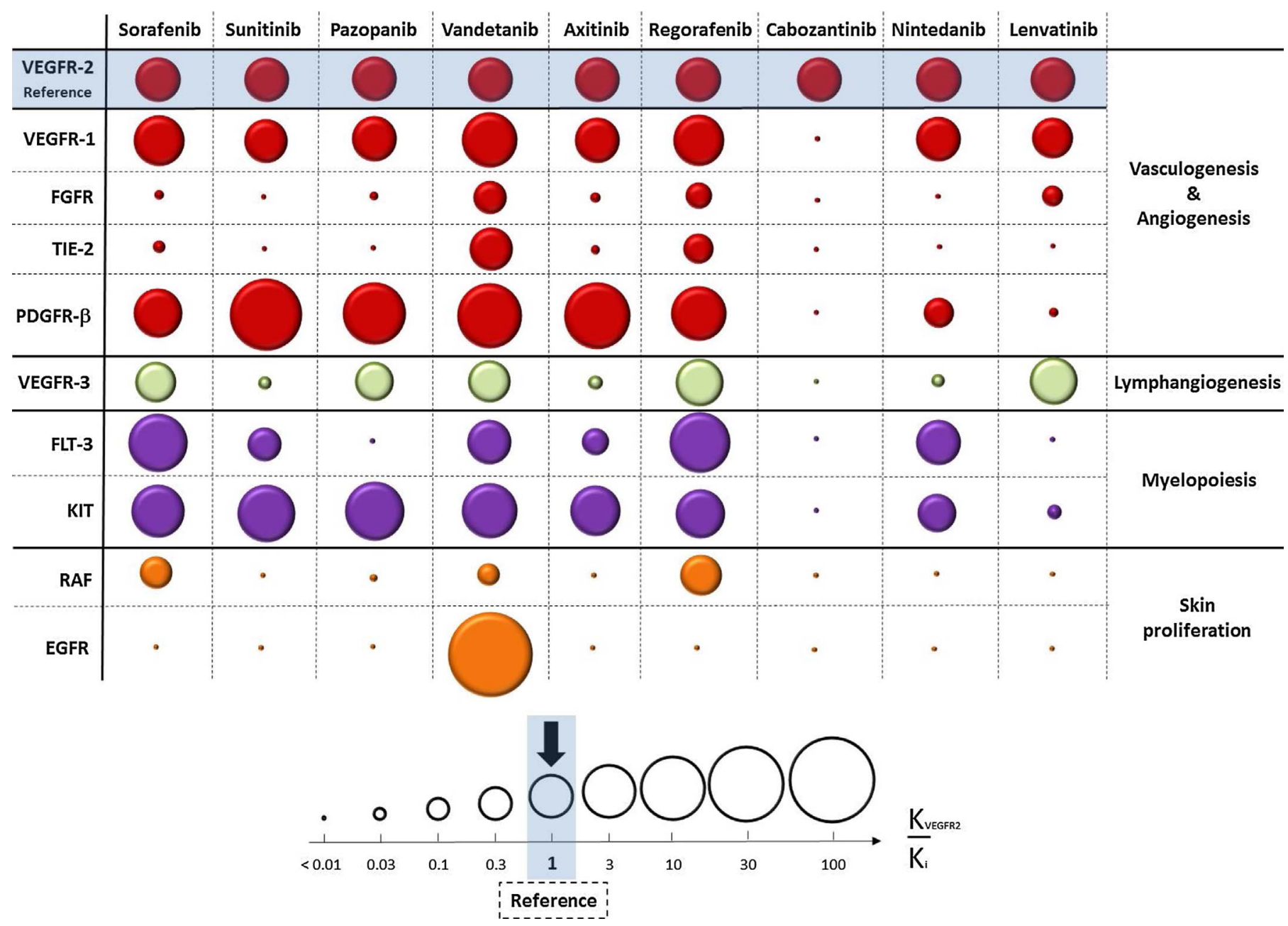

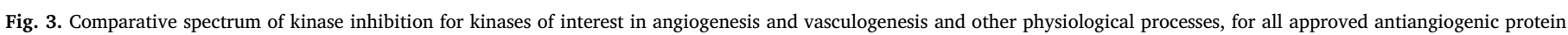
kinase inhibitors (PKIs). (For interpretation of the references to color in this figure legend, the reader is referred to the web version of this article.)

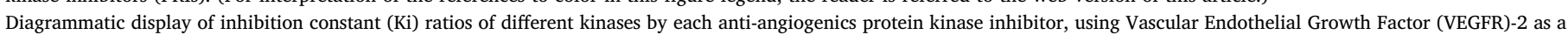

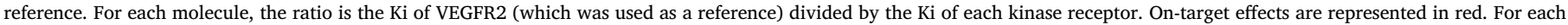
molecule, a bigger circle as compared to VEGFR2 represents a better in vitro inhibition of this kinase.

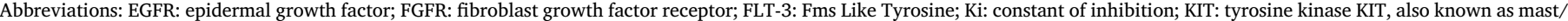

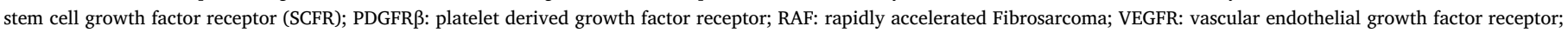

Platelet Derived Growth Factor Receptor (PDGFR) family, like PDGFR $\beta$ (Davis et al., 2011). PDGF, the ligand of PDGFR, promotes the multiplication of mesenchymal cells, particularly fibroblasts and smooth muscle cells of vessels. Imatinib, which is a PDGFR $\beta$ inhibitor could also have an anti-vascular/anti-angiogenic property by targeting vascular pericytes within the smooth muscles (Rocha et al., 2007; Ruan et al., 2013). Similarly, Fibroblast Growth Factor (FGF) and its receptors (FGFRs) also modulate blood vessel growth (Presta et al., 2005) (Figs. 2 and 3).

AA PKIs may also have co-targets unrelated to angiogenesis inhibition. For instance, a difference of affinity for Epidermal Growth Factor Receptor (EGFR) kinases might explain a difference in the incidence of acneiform rashes among PKIs (Bunn and Franklin, 2002) (Figs. 3 and 4). Similarly, inhibitors of the serine/threonine Rapidly Accelerated Fibrosarcoma (B-RAF and C-RAF) induce more skin toxicity and hand-foot skin syndrome (Sibaud et al., 2013; Urban and Anadkat, 2013) than PKIs which does not.

Of note, some PKIs inhibiting these latter pathways with no relevant effect on VEGFR pathways, might also share AA properties. As an example, imatinib inhibits PDGFR $\beta$ and has been shown to have AA properties by targeting vascular pericytes (Rocha et al., 2007; Ruan et al., 2013).

\subsubsection{Other mechanisms}

Other mechanisms inhibiting angiogenesis should be mentioned. Metronomic chemotherapy, which consists in regularly giving a small amount of drug, particularly microtubule-targeting agents, also possesses anti-angiogenic properties at non-cytotoxic levels. This effect is mediated through direct effects on vascular endothelial cells proliferation (Biziota et al., 2017; Schwartz, 2009).

\subsection{Pharmacokinetics in cancer}

\subsubsection{Antibodies and immunoglobulin derivatives intracellular targeting by PKIs}

Pharmacokinetics (PK) of anti-cancer MABs differs from that of PKIs due to their high molecular weight. Their diffusion is slow, and they have a small volume of distribution. Like most therapeutic immunoglobulin G, they have a half-life of approximately 20 days, and they are administered intravenously (Table 1). Circulating phagocytic cells degrade them into amino acids and peptides via the reticuloendothelial system (Newsome and Ernstoff, 2008). Main PK characteristics of bevacizumab, aflibercept and ramucirumab are shown in Table 1 (Han et al., 2016; Thai et al., 2013; Ohtsu et al., 2011; Spratlin et al., 2010; Caulet et al., 2016). 


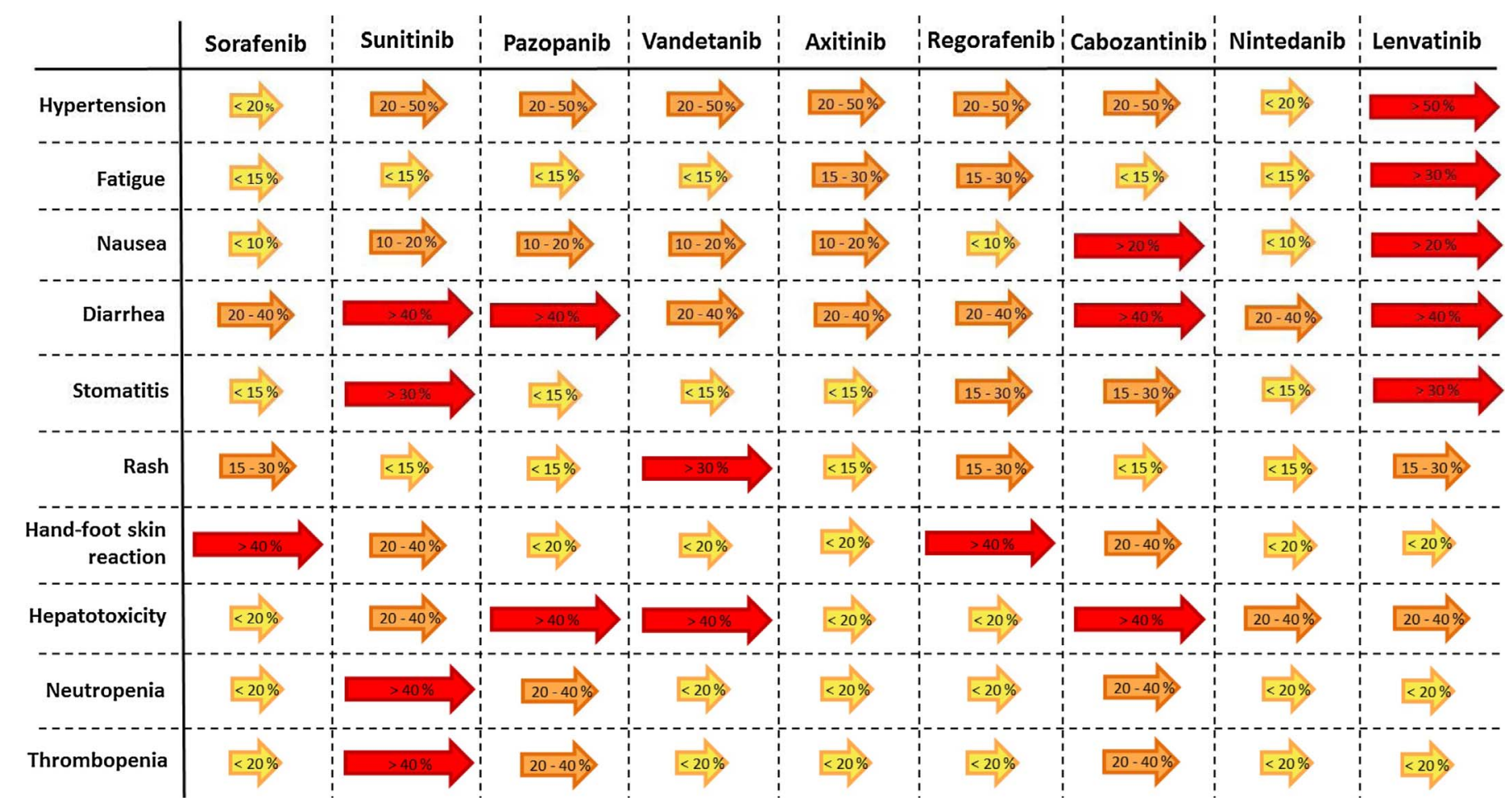

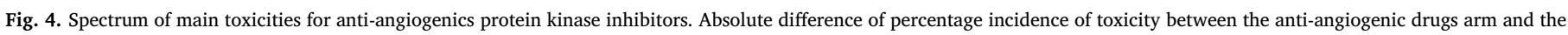
placebo/control arm in main clinical trials.

A population PK model of bevacizumab using a bicompartmental model in 1792 patients with a wide variety of cancers (Han et al., 2016) showed a central volume of distribution (V1) of $2.88 \mathrm{~L}$ and a half-life of 19.6 days (normalized to $70-\mathrm{kg}$ ) (Table 1). Clearance and V1 increased with body weight and were higher in males. Other parameters influencing pharmacokinetics were albumin and plasma levels of alkaline phosphatase. Interestingly, bevacizumab PK vary among indications. For example, bevacizumab clearance is $50 \%$ higher in gastric cancer as compared to other cancers ( $p<0.0001$, Han et al., 2014). The AVAGAST study, evaluating bevacizumab in addition to chemotherapy in gastric cancer versus chemotherapy alone, failed to significantly improve the primary endpoint of overall survival (Ohtsu et al., 2011) possibly due to higher clearance and lower plasma concentrations. Tumor burden also plays a role (Caulet et al., 2016), increasing bevacizumab's clearance.

\subsubsection{Protein kinase inhibitors}

2.2.2.1. Bioavailability. PKIs have different bioavailability, depending on their solubility, their acidy constant (pKa), their passive permeability and their affinity with carrier-mediated transporters such as P-glycoprotein (P-gp) also called ATP-binding cassette subfamily B member 1 (ABCB1) or Breast Cancer Resistance Protein (BCRP) also known as ATP-binding cassette sub-family G member 2 (ABCG2), located in the intestinal wall. We summarize bioavailability data of AA PKIs in Table 2. Of note, bariatric surgery or gastric surgery can also be of great consequence on bioavailability (van Kinschot et al., 2015).

2.2.2.2. Volume of distribution. The volume of distribution is a virtual volume in which the drug is appears to be distributed. Depending on its lipophilic-hydrophilic balance, a drug diffuses more or less in different tissues. Patient's lean body mass and visceral fat influence the volume of distribution of the drug. Obese patients have a very different volume of distribution and PK than non-obese patients (Lemmens and Ingrande, 2013). No trial and only a few case reports have investigated on the role of obesity on PK of AA PKIs (Desar et al., 2009).
2.2.2.3. Drug metabolism and hepatic elimination. PKIs are mostly metabolized by the liver, through phase 1 (oxido-reduction reactions, mainly CYP3A4) and phase 2 reactions (glucosyl conjugation by UDPglucuronosyltransferase like UGT1A1 for instance). Details concerning the metabolism of AA PKIs are provided in Table 2. Due to its frequent liver toxicity, cabozantinib dosage should be reduced in patients with Child-Pugh score A or B (Herbrink et al., 2015) and is contraindicated in patients with Child-Pugh score C. Dose adaptations for other PKIs are reported in Table 3.

2.2.2.4. Active metabolites. Sunitinib and regorafenib are PKIs which form active metabolites. Regorafenib has 2 active metabolites, M-2 and M-5. They have shown similar kinase inhibition profile as the parent drug in a preclinical model. Other approved AA PKIs do not form active metabolites.

2.2.2.5. Renal elimination. Except for vandetanib, most PKIs have a very limited renal clearance. Therefore, dose adaptation according to renal impairment is rarely required for most AA PKIs (Table 3). Vandetanib dose should be reduced to $200 \mathrm{mg}$ once daily in patients with moderate renal insufficiency (creatinine clearance $<50 \mathrm{~mL} / \mathrm{min}$ ). Intriguingly, sunitinib and its main active metabolite SU12662 are not dialyzable but the mean plasma concentration of sunitinib is lower in patients with chronic hemodialysis as compared to patients with or without severe renal impairment: maximum concentration (Cmax) and area under curve (AUC) have a hemodialyzed vs. normal ratio of 0.70 and 0.69 (90\% confidence interval (CI) [54-90]) and [54-87], respectively (Josephs et al., 2011; Khosravan et al., 2010). Thus, Sunitinib is used at similar doses in patients with or without severe renal impairment or need for hemodialysis.

2.2.2.6. Sunitinib oral regimen. Most PKIs are administered orally and continuously. However, sunitinib was originally designed to be administered by sequences of 4 weeks ON ( $50 \mathrm{mg}$ once a day) followed by two weeks OFF. Other schemes were tried (Escudier et al., 2009). In a randomized trial, the $37.5 \mathrm{mg}$ continuous regimen 


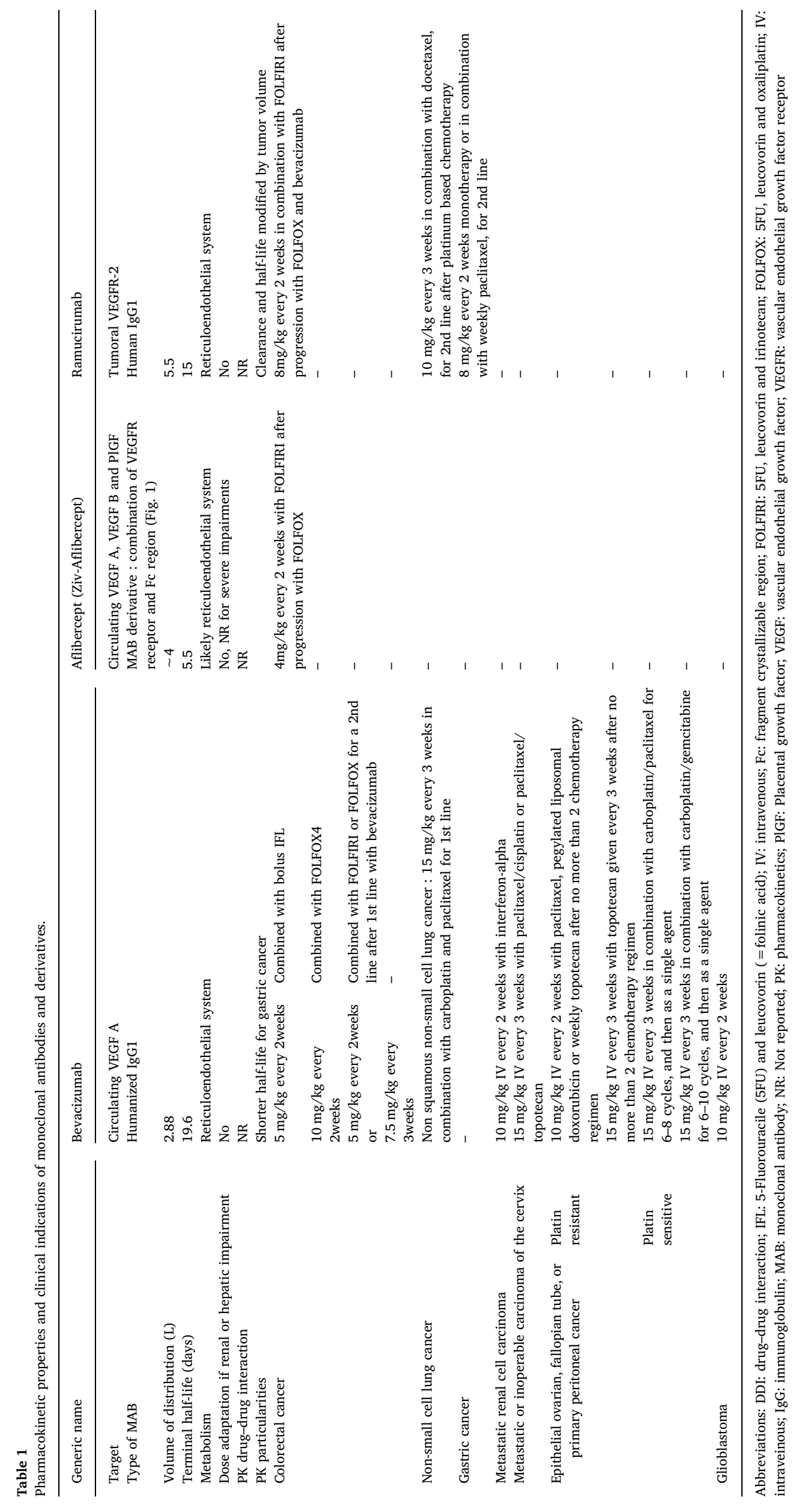




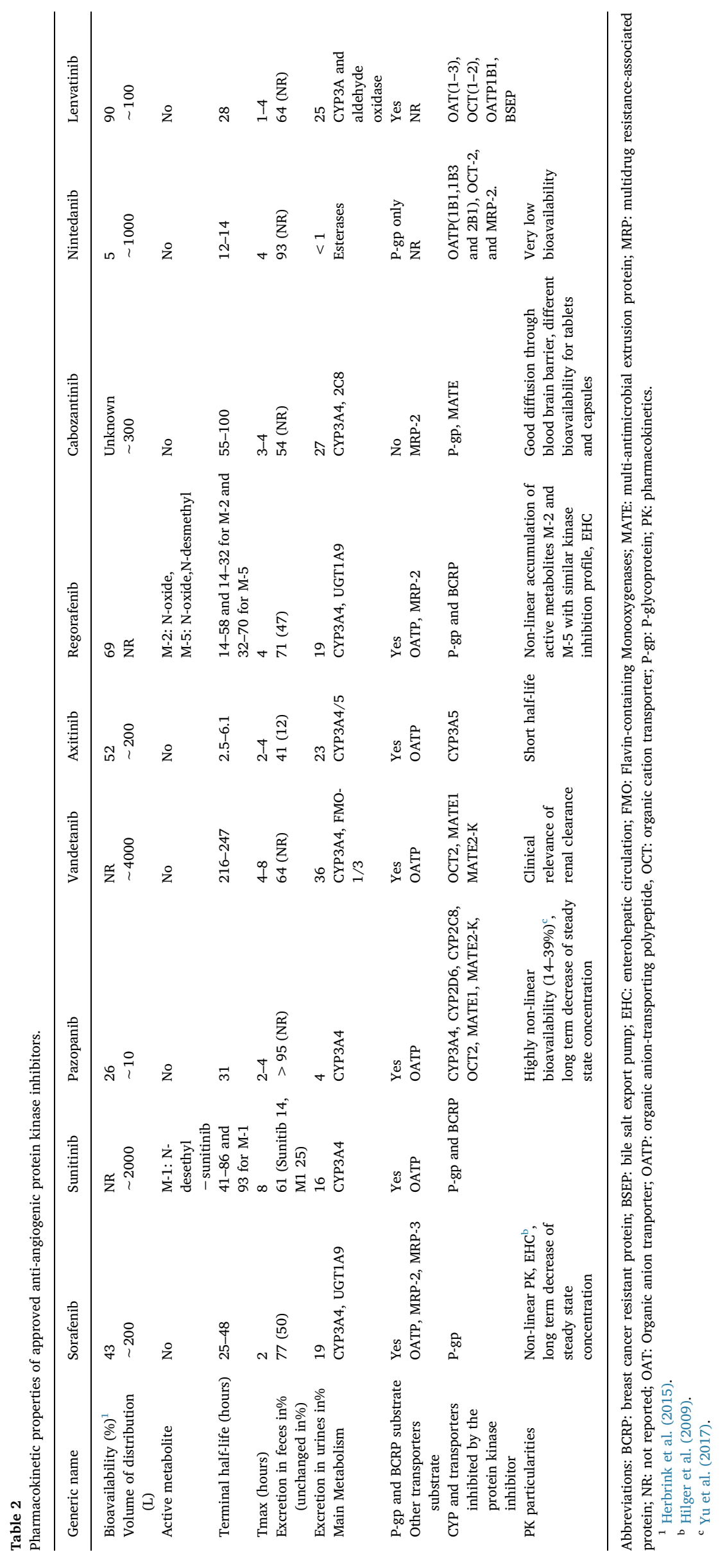




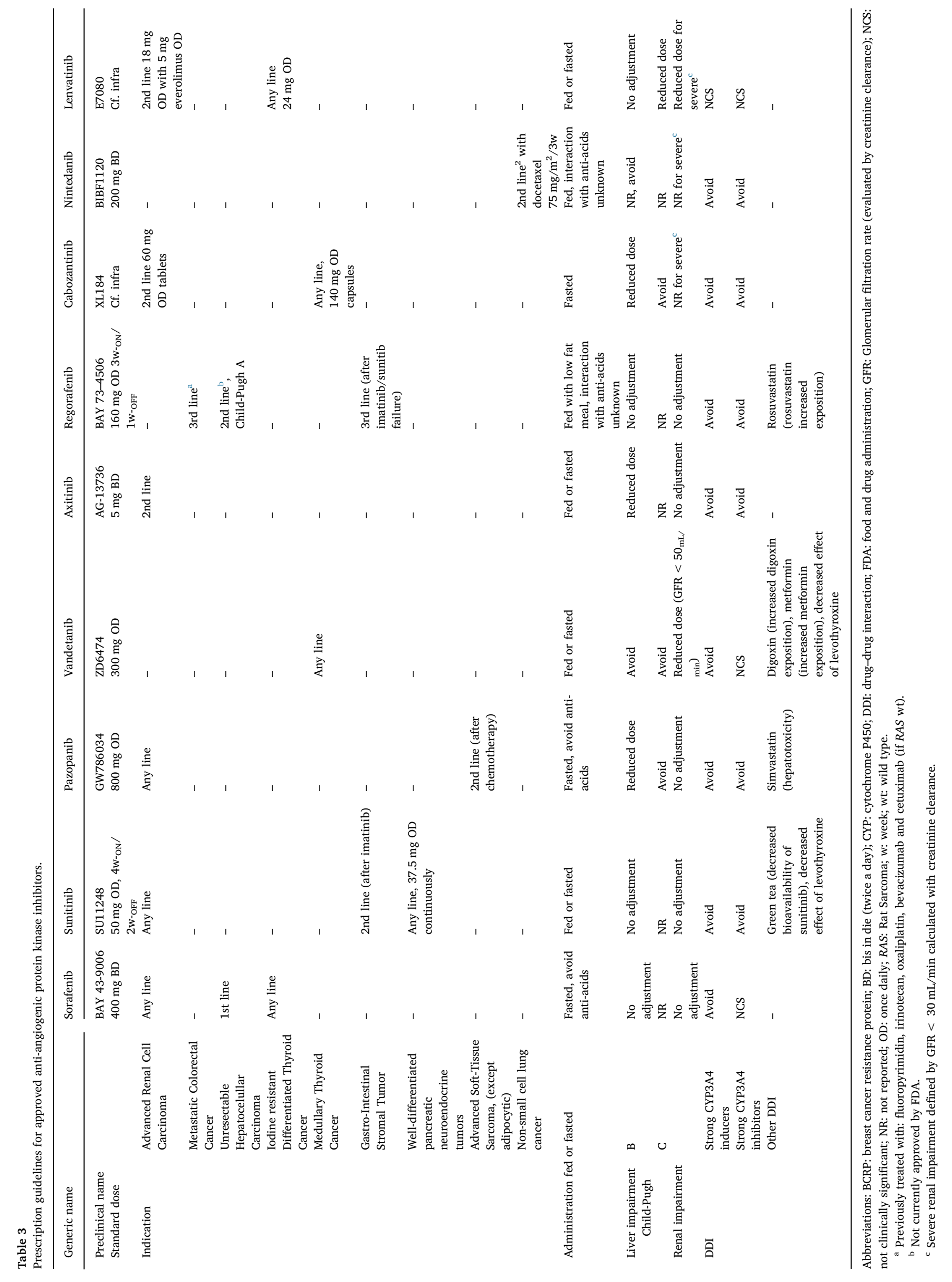


had a trend to a worse time to progression when compared to $4 / 2 \mathrm{wk}$ regimen (7.1 vs 9.9 months, $\mathrm{p}=0.09$, respectively) (Motzer et al., 2012). It was suggested that the intermittent dosing had a better activity, although it is counterintuitive that an AA drug would be more effective in an intermittent rather than in a continuous regimen. The RESTORE study (Lee et al., 2015a,b) also compared different dosing regimens for the treatment of clear cell renal cell carcinomas (CCRCC). Lee et al. compared a 2-week ON, 1 week OFF regimen, which tended to improve the rate of failure free survival at 6 months when compared to the $4 / 2$ regimen ( $63 \%$ vs $44 \%$, not clinically significant) and appeared to have a better safety profile.

\subsection{Potential for drug interactions}

\subsubsection{Pharmacokinetic interactions}

MABs and derivatives

Most monoclonal antibodies are not subject to drug-drug interactions (DDI) (Keizer et al., 2010). Mabs elimination is related to immune system (phagocytosis), and therefore immunosuppressive drugs can have a measurable effect on mabs PK (Keizer et al., 2010).

2.3.1.1. Gastric acidity. Anti-acid drugs modify gastric acidity. Some drugs like pazopanib are multiple acids with different pKa. Depending on their acid form, they are more or less ionized. Ionized forms have a better solubility in water and a very low passive diffusion through membrane barriers. Acidity is therefore critical for drug solubility and absorption. While on $40 \mathrm{mg}$ esomeprazole daily, pazopanib $\mathrm{AUC}_{0-24}$ and Cmax decreased by 40 and 42\%, respectively (Tan et al., 2013). Therefore, pazopanib and anti-acids should not be used concomitantly (Table 3). Recommendations concerning AA PKIs intake fed or fasted and main interactions with drugs modifying gastric acidity are summarized in Table 3.

2.3.1.2. CYP interaction. Most PKIs are predominantly eliminated by the liver, mainly by cytochromes P-450 (CYP) pathways (Rowland et al., 2017). Table 3 summarizes known DDIs for each PKI and recommendations concerning dose adaptations in case of liver impairment. Association with CYP inhibitors or inducers (mainly CYP 3A4/5) should be avoided for most PKIs. Of note, main CYP3A4/5 inhibitors include azole antifungals (ketoconazole and itraconazole among others), ritonavir, macrolides (erythromycin and clarithromycin) and grapefruit juice. CYP3A4 inducers include antiretrovirals (efavirenz, nevirapin), barbiturates, carbamazepine, rifampin, glucocorticoids, and Saint-John's wort.

\subsubsection{Pharmacodynamic interactions}

Considering the increased risk of bleeding with all AA drugs, particularly in colorectal cancer and lung cancer (cf. $§ 1.5$ ), a particular caution should be given to the association of anticoagulants or antiplatelets drugs.

The use of simvastatin concomitantly with pazopanib increases the risk of transaminase elevation ( $\mathrm{Xu}$ et al., 2012). Other interactions (Table 3) have been described including the precipitation of sunitinib with concomitant green tea (Ge et al., 2011) with a decrease of Cmax and AUC of $50 \%(\mathrm{p}<00.1)$ when sunitinib is administered with green tea extracts compared to water in preclinical models. Another described interaction is the decreased effect of levothyroxine due to sunitinib and vandetanib (de Groot et al., 2006).

\subsubsection{Pharmacogenetic interactions}

Many findings about polymorphisms of CYP or drug transporters and their role in the elimination of PKIs have been reported. Some results were controversial (Erdem et al., 2012; Pander et al., 2010). Most studies did not show a clinically significant relevance for these polymorphisms. As an example, CYP3A4 variants change sunitinib and SU12662 clearance, but the effect is below inter-individual variability
(Diekstra et al., 2014). However, 421-AA genotype of adenosine triphosphate binding cassette subfamily G member 2 was associated with more sunitinib-related toxicity in a Korean population (Kim et al., 2013). In the E2100 study which assessed efficacy of bevacizumab combined with paclitaxel or placebo in metastatic breast cancer, Schneider et al., also demonstrated an influence of VEGF 2578-AA genotype on the outcome under bevacizumab. This genotype was associated with a better overall survival and a higher risk of hypertension (Schneider et al., 2008).

\subsection{Different indications of angiogenesis inhibitors based on cancer types}

All approved AA inhibit at least the VEGF/VEGFR-2 pathway. However, they do not share the same selectivity for other on-target (VEFGFR1, VEGFR2 for example) or off-target kinases such as RAF (Fig. 3). Therefore, they do not have the same clinical efficacy on different cancer types (Table 3) or the same spectrum of side effects (Fig. 4).

\subsubsection{Metastatic clear cell renal cell carcinoma}

Most (90\%) CCRCC have a mutation of the Von Hippel Lindau protein (pVHL), a tumor suppressor. In normal cells and under normoxic conditions, pVHL binds to the Hypoxia Inducible Factor (HIF) to promote its ubiquitination and degradation. The loss of pVHL function leads to a constant activation of HIF and an upregulation of VEGF among other pro-angiogenic factors (Frew and Moch, 2015). Although chemotherapy and radiotherapy are both inefficient, many drugs inhibiting the VEGF-VEGFR pathway improve the overall outcome in patients with metastatic CCRCC (mCCRCC).

Sorafenib was the first drug in the protein kinase inhibitor class to be approved for mCCRCC. It was first developed for its activity against RAF-1, but sorafenib also had a broad-spectrum tyrosine kinase inhibition including most receptors implicated in angiogenesis processes including VEGFR-2 (Fig. 2). Sorafenib improved progression-free survival (PFS) as compared to placebo (5.5 vs. 2.8 months, $\mathrm{p}<0.01)$ (Escudier et al., 2007a).

Sunitinib is another VEGFR inhibitor and was approved for the same indication than sorafenib one month later. Sunitinib improved PFS, as compared to interferon alpha (11 vs. 5 months, $\mathrm{p}<0.001$ ) (Motzer et al., 2007). Although the populations of these phase 3 trials were not similar, sunitinib provided a higher response rate than sorafenib $(31 \%$ vs. $10 \%$, respectively). Of note, differences in the spectrum of kinase inhibition between these two drugs might explain the differences in both efficacy and safety (Figs. 3 and 4) (Stein and Flaherty, 2007).

Other AA PKIs were later developed for this indication. In a phase 2 open label study in mainly treatment naïve (69\%) patients, pazopanib had an interesting activity with a PFS of 12 months and an overall response rate (ORR) of 35\% (Hutson et al., 2010). In another randomized phase 3 trial, pazopanib was also non-inferior to sunitinib and showed a better safety profile and a better quality of life in first line (Motzer et al., 2013). Axitinib was developed to have a more specific activity against VEGFR family receptors, and less off-target side effects (Figs. 3 and 4). Rini et al. explored the possibility of drug titration for axitinib in a trial allowing axitinib increased dosage in case of good tolerance compared to no axitinib adaptation (Rini et al., 2013). The ORR was higher in the axitinib adaptation dose group (ORR $=54 \%$ vs. $34 \%, \mathrm{p}=0.019$ ). The dose increase from $5 \mathrm{mg}$ bid to $7 \mathrm{mg}$ bid was allowed for patients with blood pressure $\leq 150 / 90 \mathrm{mmHg}$ on no more than two antihypertensive drugs and no other grade 3-4 treatment-related toxic effects. Axitinib also improved PFS, as compared to sorafenib as a second line therapy (6.7 vs. 4.7 months, $\mathrm{p}<0.0001$ ) (Rini et al., 2011).

Sorafenib, sunitinib pazopanib and axitinib have an activity against PDGFa and Stem Cell Factor Receptor, also known as c-KIT. Cabozantinib does not, and its spectrum of inhibition includes Mesenchymal-Epithelial Transition factor (c-MET), Rearranged during Transfection (RET) and AXL receptor tyrosine kinase in addition to 
VEGFR. Recently, it was shown in the CABOSUN phase 2 trial that cabozantinib improved the PFS as compared to sunitinib in a first-line therapy (8.2 vs. 5.6 months, $\mathrm{p}=0.012$, respectively), with similar safety profile (Choueiri et al., 2017). Further investigations might be needed to make cabozantinib a standard in first line in mCCRCC treatment. Cabozantinib was also randomized against everolimus, an mTOR inhibitor, in a phase 3 trial in second line, with a significant improvement in the overall survival (21.4 months vs. 16.5, $\mathrm{p}<0.001$ ) (Choueiri et al., 2016).

Finally, lenvatinib, a PKI with a dual VEGFR and pan-FGFR activity (Fig. 3), in association with everolimus was also approved by the Food and Drug Agency (FDA) for the treatment of mCCRCC following one prior AA. The combination had an important activity but was more toxic than other PKIs in monotherapy (Fig. 4).

Among MABs, bevacizumab was evaluated in combination with interferon alpha-2a, which was the standard of care at that time (Escudier et al., 2007b). Despite a notable activity, this combination has been largely abandoned, due to the poor tolerance of interferon and the induced fatigue.

\subsection{Choice of PKI for mCCRCC}

In a recent meta-analysis, Rousseau et al. showed that the different AA PKIs (sunitinib, pazopanib, sorafenib, axitinib) and the association of bevacizumab plus interferon had similar efficacy on overall survival in first line when treating mCCRCC (Rousseau et al., 2016). This study supports the view that choice of AA PKI in this indication may be driven by its safety profile more than by its efficacy. Main toxicities with the different AA PKIs are summarized in Fig. 4. Briefly, sorafenib is associated with more hand-foot syndromes, and less nausea and anorexia. Sunitinib increases hematological toxicities (mainly neutropenia and thrombocytopenia) and anorexia. Pazopanib is associated with less fatigue and hand-foot skin reaction than sunitinib, but more liver toxicities (Motzer, 2016), and had a better quality of life score as compared to sunitinib, in the COMPARZ trial (Motzer et al., 2013). In the doubleblind PISCES trial, Escudier et al. randomized patients in a cross-over scheme to receive either sunitinib or pazopanib (Escudier et al., 2014). The primary outcome was the patients' preference for the PKI administered: Pazopanib was preferred to sunitinib (70 vs. $22 \%$, $\mathrm{p}<0.001$ ) with $8 \%$ of patients having no preference. Pazopanib also had better results as compared to sunitinib on measures evaluating fatigue, hand-foot skin reaction, and mouth/throat soreness.

Of note, the ability of cabozantinib to cross the blood-brain barrier as compared to other approved PKIs in mCCRCC raises the question of a potential increased beneficial effect in case of brain metastases (Abdelaziz and Vaishampayan, 2017). Clinical trials to evaluate such specific subpopulations need further evaluation. Finally, the approval of the immune checkpoint inhibitor nivolumab as second line in $\mathrm{mC}$ CRCC treatment also introduces complexity in the choice of the best sequence (Malouf et al., 2016).

\subsubsection{Advanced hepatocellular carcinoma}

Hepatocarcinoma (HCC) has two specific features. First, they are highly vascularized. As a consequence, they are hyperdense during the hepatic arterial phase on a multiphase perfusion CT-scan and then have an early wash-out. Second, most patients with HCC have underlying liver cirrhosis and many comorbidities.

In a randomized placebo controlled phase III trials, sorafenib, improved overall survival in patients with advanced HCC (Llovet et al., 2008) with a median overall survival which was increased from 7.9 months to 10.7 months compared to placebo ( $\mathrm{p}<0.001$ ). Interestingly, the phase 1 trial of sorafenib concluded to the same maximum tolerated dose in patients treated for non-resectable HCC compared to other cancers, despite significant liver dysfunction in this population, with no PK difference between Child-Pugh A and Child-Pugh B patients (Abou-Alfa et al., 2006).
Regorafenib is active on many other pathways than VEGF/VEGFR2, namely: Tyrosine kinase with Immunoglobulin-like and EGF-like domains (TIE-2)/angiopoietin-1 (Ang1), PDGF/PDGFR, FGF/FGFR. In patients with advanced HCC previously treated with sorafenib Bruix et al. showed an increase of 3 months in overall survival (10.6 months vs 7.8 months, $\mathrm{p}<0.0001$ ) with regorafenib compared to placebo (Bruix et al., 2017).

\subsubsection{Thyroid cancer}

Like HCC and CCRCC, differentiated thyroid cancers (DTC) are also hyper vascularized. Lenvatinib, a PKI with a very large spectrum (Fig. 3), was particularly efficacious for the treatment of radioiodineresistant DTC. In the SELECT phase 3 trial, the PFS was 18.3 months compared to 3.6 months in the placebo group (HR $=0.21, \mathrm{p}<0.001$ ), with a response rate of $64.9 \%$ compared to $1.5 \%$ in the placebo group (Schlumberger et al., 2015). Sorafenib was assessed in a phase III and vandetanib was also assessed in a phase II, both compared to placebo in the same indication. Sorafenib was approved and vandetanib showed some activity. They both seemed less efficient than lenvatinib but they were also less toxic than lenvatinib, and the benefit of lenvatinib on overall survival has not been demonstrated yet. It should be noted that at the standard dose of $400 \mathrm{bid}$, more toxicities were observed with sorafenib in the DTC population than in the HCC and the RCC populations (Jean et al., 2016).

Medullary thyroid cancer (MTC) oncogenesis mostly happens through a sporadic or a congenital mutation of the RET oncogene. Vandetanib (Wells et al., 2012) and cabozantinib (Elisei et al., 2013) are two dual inhibitors of VEGFR and RET pathways, and they both proved to be effective in patients with advanced MTC.

\subsubsection{Metastatic colorectal cancer}

RAS-mutated metastatic colorectal cancer (mCRC), representing $50 \%$ of mCRC cases, are resistant to cetuximab and panitumumab, two MABs targeting EGFR. Bevacizumab, in contrast, is active in both RASmutated and RAS wild-type mCRC patients. A phase 2 study comparing Leucovorin and 5-Fluorouracil (LV5FU2 regimen) versus LV5FU2 plus bevacizumab, showed an increase of the PFS (5.5 vs. 10.2 months). However, the primary endpoint was overall survival which was not significantly improved (Kabbinavar et al., 2003). A phase 3 trial comparing FOLFIRI (Folinic acid, 5-Fluorouracil, and Irinotecan) and FOLFIRI plus bevacizumab for mCRC, confirmed a higher PFS with the adjunction of bevacizumab, independently of the KRAS status(Hurwitz et al., 2004). In the FIRE-3 study, comparing FOLFIRI plus cetuximab versus FOLFIRI plus bevacizumab in mCRC harboring a KRAS mutation, there was no significant difference in the overall response rate $(62 \%$ vs $58 \%$, respectively, odds ratio $(\mathrm{OR})=1.18, \mathrm{p}=0.18$ ) which was the primary endpoint. However, the cetuximab arm had a better median overall survival (28.7 months vs 25.0 months, $\mathrm{p}=0.017$ ) (Heinemann et al., 2014).

Aflibercept also proved to be useful, as a second line therapy and combined with FOLFIRI (Van Cutsem et al., 2012). But the modest improvement in the overall survival (13.5 vs. 12.0 months) was balanced with a significant increase in toxicities and cost (Wade et al., 2015). In addition, only $30.5 \%$ of the patients had previously received bevacizumab.

The RAISE trial compared FOLFIRI with Ramucirumab or FOLFIRI with a placebo, in patients who progressed after a prior therapy combining oxaliplatin, fluoropyrimidine, and bevacizumab, and found a benefit on overall survival (13.3 vs. 11.7 months, $p=0.022$ ) which was the primary endpoint (Tabernero et al., 2015).

Regorafenib is the only PKI approved in the management of mCRC, after showing a benefit in the CORRECT study (Grothey et al., 2013). Interestingly, all patients were previously treated with bevacizumab. In comparison with the placebo, the increase of overall survival was modest, 6.4 months vs. 5.0 (hazard ratio $=0.77, \mathrm{p}=0.0052$ ), but the population of the study was heavily pre-treated. To date, aflibercept, 
ramucirumab and regorafenib are not standards of care because of their modest activity balanced with their significant toxicity and cost. However, patients often have no standard of care left at this stage of the disease, and these treatments significantly improved overall survival. They could therefore be considered as an option for patients with a good performance status and no limiting cardio-vascular comorbidities.

\subsubsection{Sarcomas}

Sunitinib and regorafenib are two inhibitors of c-KIT (Fig. 3), encoded by the KIT oncogene which is an important driver mutation in gastro-intestinal stromal tumors (GISTs). They were both approved, in second and third line of treatment respectively, in this indication (Demetri et al., 2006, 2013).

In the REGOSARC study (Mir et al., 2016) regorafenib had a promising activity in advanced soft-tissue sarcoma refractory to doxorubicin, particularly in the synovial sarcoma cohort (PFS: 5.6 months with regorafenib vs. 1.0 months with placebo, $p<0.0001$ ), and the leiomyosarcoma cohort (PFS: 3.7 vs. 1.8 months, $p=0.0045$ ). No activity was found in liposarcoma. For other soft-tissue sarcomas, PFS was 2.9 months versus $1.0(p=0.0061)$.

\subsubsection{Glioblastomas}

Bevacizumab has been approved by the FDA for the treatment of glioblastomas in monotherapy. Vredenburgh and others identified an unprecedented activity of bevacizumab in combination to irinotecan in recurrent glioblastoma, with a response rate of $57 \%$ (Vredenburgh et al., 2007). This "anti-glioma" activity was later confirmed with bevacizumab monotherapy (Kreisl et al., 2009), in a heavily pretreated glioblastoma population, although this study had no control group. However, it failed to improve the overall survival and the quality of life in combination to first line radiochemotherapy (Gilbert et al., 2014; Taphoorn et al., 2015). Its role in glioblastoma remains debated: no data has shown a benefit of bevacizumab on overall survival so far, despite an improvement in PFS, and bevacizumab has never been compared to placebo.

\subsubsection{Other indications of anti-angiogenics in combination with cytotoxic} chemotherapy

2.5.6.1. Rationale for combining $A A$ and chemotherapy. Originally, AA were supposed to starve tumors, reversing the so-called "angiogenic switch" (Hanahan and Folkman, 1996). Most tumors have a very abnormal and heterogeneous vasculature, and some areas of the tumor are hypoxic and poorly perfused. Jain et al. suggested that AA could temporarily "normalize" this vasculature, therefore increasing the perfusion of the tumor and the benefit of a combination of AA with chemotherapy (Jain, 2005).

2.5.6.2. Combining $A A M A B s$ with chemotherapy. An important number of bevacizumab plus chemotherapy combinations demonstrated a significant increase of the PFS but no significant benefit on overall survival in various cancer types (Miles et al., 2010; Miller et al., 2007; Robert et al., 2011; Van Cutsem et al., 2009). Some indications of bevacizumab have been approved at $2.5 \mathrm{mg} / \mathrm{kg}$ per week (equivalent to $7.5 \mathrm{mg} / \mathrm{kg}$ every 3 weeks). Others have been approved at $5 \mathrm{mg} / \mathrm{kg}$ per week $(15 \mathrm{mg} / \mathrm{kg}$ every 3 weeks).

Similarly to bevacizumab, ramucirumab was approved in second line for gastric or gastro-esophageal junction adenocarcinoma. It was also approved in second line in combination to docetaxel for non-small cell lung cancer (Tabernero et al., 2015).

2.5.6.3. Combination with PKIs. Many phase 3 trials in different cancer types failed to prove the efficiency of AA PKIs combined to cytotoxic chemotherapy and often showed a poorer safety profile (Bergh et al., 2012; Carrato et al., 2013; Crown et al., 2013; Flaherty et al., 2013; Gonçalves et al., 2012; Hauschild et al., 2009; Scagliotti et al., 2010). Nintedanib is the only exception: compared to placebo and combined to docetaxel in previously treated lung adenocarcinoma. Nindetanib increased overall survival (10.9 months vs 7.9 months, $\mathrm{p}=0.007$ ) (Reck et al., 2014), with an important increase of the rate of diarrheas (Fig. 4). However, in this study, only $4 \%$ of the study population was previously treated with bevacizumab. Nintedanib was approved by the European Medicines Agency (EMA) in this setting, but not by the FDA.

\subsection{Adverse effects of anti-angiogenics}

\subsubsection{Common to the angiogenesis inhibitor class}

2.6.1.1. Hypertension. VEGF, through the receptor VEGFR-2, upregulates the endothelial nitric oxide synthase enzyme, responsible for the nitric oxide (NO) production. NO is a known vasodilator, and its inhibition results in hypertension. Moreover, microvascular endothelial cell rarefaction leads to a decrease in microvessel density (León-Mateos et al., 2015), and an increase in peripheral hydraulic resistance. Therefore, any drug targeting the VEGF-VEGFR pathway can induce hypertension. The kinetics of blood pressure rise is drug-dependent, but the increase in blood pressure generally occurs within the first days of treatment. Apparition of hypertension is dose-dependent and has been suggested as a surrogate of an effective inhibition of VEGF pathway (Zhu et al., 2007).

In a meta-analysis on 1032 patients developing hypertension under bevacizumab, 4 developed hypertensive encephalopathy, and 17 had uncontrolled hypertension that resulted in either bevacizumab discontinuation or hospitalization (Zhu et al., 2007). A pooled meta-analysis of 3745 patients treated for non-small cell lung cancer (NSCLC) with chemotherapy with or without bevacizumab found a higher risk of hypertension in the bevacizumab arm as compared to chemotherapy alone ( $8.2 \%$ vs $1.7 \%$, grade $3-4$ hypertension, $\mathrm{p}<0.001$, respectively) (Lai et al., 2016). The risk of hypertension with all AA is generally higher among the CCRCC population as compared to other cancers ( $\mathrm{Li}$ et al., 2014). Vascular-selective calcium channel blockers such as amlodipine seem to control bevacizumab-induced hypertension in most cases (Mir et al., 2012a,b). Renin-Angiotensin-Aldosterone System inhibitors can also be used, although they might be less effective according to preclinical studies (de Jesus-Gonzalez et al., 2012; Lankhorst et al., 2014).

\subsubsection{Proteinuria}

Proteinuria is another common adverse event that needs to be monitored. When VEGF is inhibited, glomerular capsule podocytes lose their healthy fenestrated phenotype. Some preeclampsia-like syndromes associating hypertension, proteinuria, and edema have been reported with sorafenib and sunitinib (Patel et al., 2008). In the Lai et al. meta-analysis, $2.5 \%$ patients on bevacizumab plus chemotherapy had proteinuria compared to $0 \%$ with chemotherapy alone (Lai et al., 2016). The Incidence of proteinuria is independent of the occurrence of hypertension. Izzedine et al. proposed an early referral to a nephrologist in case of pre-existing renal insufficiency or renal comorbidities. Urine dipstick analysis should be performed at each clinical work-up. When the dipstick is positive for proteinuria, quantitative measurement should be performed. A proteinuria $>1 \mathrm{~g} / \mathrm{L}$ should be a limit to stop the treatment and lead to a nephrologist referral (Izzedine et al., 2010). It has been proposed to treat hyperproteinuria $>0.3 \mathrm{~g} / \mathrm{L}$ associated with a hypertension $>130 / 80 \mathrm{mmHg}$ with an AngiotensinConversing Enzyme (ACE) or an Angiotensin II Receptor Antagonists (ARA II) (Izzedine et al., 2010). Inhibition of VEGF or VEGFR-2 can also result in glomerular endothelium damages characterized by swelling, development of microvascular injury and thrombotic microangiopathy (Eremina et al., 2008).

2.6.2.1. Hemorrhage and thrombo-embolic events. Hemorrhage is another class effect adverse event (Zhu et al., 2016). As compared to chemotherapy alone, the relative risk (RR) of bleeding on chemotherapy with bevacizumab is between 2-3 for most cancers, 
depending on bevacizumab dosage. The risk of fatal bleeding is less than $1 \%$ in most cancer types, except for lung cancer ( $R R=5.02,95 \%$ CI: 1.52-16.66, absolute percentages not given) (Hapani et al., 2010).

Depending on the indication, bevacizumab does not have the same reported profile of toxicities. Lai et al., did not find a significant increase in the risk of venous or arterial thrombotic event or gastro-intestinal (GI) perforations in the NSCLC population (Lai et al., 2016), although the risk of GI perforations was tripled in metastatic colorectal cancer $(2.2 \%$ versus $0.7 \%, \mathrm{OR}=3.21,95 \%$ CI: $1.72-6.01)$ (Hurwitz et al., 2013) and in ovarian cancer (RR 2.76, 95\%CI: 1.51-5.03) (Wu et al., 2017).

In a meta-analysis of different phase 2 and 3 trials, Hurwitz et al. concluded that there was no significant increase of thrombo-embolic events with bevacizumab compared to placebo (Hurwitz et al., 2011). In another meta-analysis, Nalluri et al. concluded differently, with a higher risk of thrombo-embolic events in the bevacizumab group compared to placebo, with no effect of the dose: low dose $(2.5 \mathrm{mg} / \mathrm{kg}$ / week) $\quad \mathrm{RR}=1.31, \quad \mathrm{p}=0.007$ and high dose $(5 \mathrm{mg} / \mathrm{kg} /$ week $)$ $\mathrm{RR}=1.31 \mathrm{p}=0.04$ (Nalluri et al., 2008).

2.6.2.2. Cardiac toxicity. Inhibitors of the VEGF/VEGFR pathway can cause reversible or irreversible cardiac toxicity (Zamorano et al., 2016). In the BEATRICE trial, which assessed adjuvant bevacizumab in combination with chemotherapy in adjuvant setting for triple negative breast cancer, bevacizumab induced $2 \%$ of left ventricle dysfunction and $1 \%$ of heart failure (no event in the placebo plus chemotherapy group) (Cameron et al., 2013). The relative risk of congestive heart failure is increased with AA, although it is unclear whether the differential spectrum of kinase inhibited by AA plays a role or not (Qi et al., 2014a, 2014b). Similarly, a meta-analysis conducted on 10647 patients showed an increased incidence of all grades heart failures (HF) with AA PKIs as compared to control group not receiving such PKIs (RR $=2.69,95 \%$ CI: $1.86-3.87$ ) of (Ghatalia et al., 2015).

Patras de Compaigno et al. analyzed the proportion of $\mathrm{HF}$ in the WHO safety report database (VigiBase ${ }^{\circ}$ ) for different PKIs. They investigated the link between the proportion of $\mathrm{HF}$ incidence and their kinome profile (Patras de Campaigno et al., 2017). Level of inhibition of ABL1 and ABL2 protein kinase was significantly correlated to the proportion of HF. This could explain why sunitinib induces more HF than other AA PKIs.

2.6.2.3. Other toxicities. Posterior reversible encephalopathy syndrome (PRES) is another rare, but sometimes lethal, adverse effect of bevacizumab (Singer et al., 2015). This syndrome should be considered when dealing with unexpected encephalopathy symptoms, seizure, headache, visual abnormalities or acute hypertension. Case reports of PRES have also been reported with sorafenib, sunitinib, and pazopanib (Chelis et al., 2012; Cumurciuc et al., 2008; Hadj et al., 2012; Laruelle et al., 2016). A phase 2 trial evaluating aflibercept $v s$. placebo in association with cisplatin and pemetrexed in NSCLC was prematurely stopped due to an unexpected rate of PRES: 3 confirmed and 2 suspected cases among 42 randomized patients (Chen et al., 2014).

VEGF plays an important role in different steps of wound healing: phagocytosis, coagulation, chemotaxis, mitogenesis, and synthesis of collagen and other matrix components (Sharma and Marcus, 2013). As compared to chemotherapy alone, addition of AA delays wound healing and increases surgery complications. Scappaticci et al. evaluated that bevacizumab increased the risk of serious wound healing complication in colorectal cancer when the last bevacizumab injection was $<60$ days (Scappaticci et al., 2005).

Osteonecrosis of the jaw is a serious side effect of bisphosphonate and denosumab. Concomitant use of AA might increase the risk of osteonecrosis (Christodoulou et al., 2009; Vrdoljak et al., 2013) although results are conflicting (Smidt-Hansen et al., 2013).

Fetal toxicity and teratogenicity are another toxicity of AA. A chicken embryo model showed a similar effect of a wide panel of AA on embryos vasculature at relevant doses (Beedie et al., 2016).

\subsubsection{Adverse effects specific to antibodies and derivatives}

Like any monoclonal antibody, bevacizumab injection can be accompanied by $\approx 3 \%$ of skin reactions during the infusion, of which $0.2 \%$ are severe and associated with features of anaphylaxis (Guan et al., 2015). Bevacizumab and ramucirumab adjunction to chemotherapy often have been reported to increase hematological toxicities such as febrile neutropenia (Rossari et al., 2012; von Minckwitz et al., 2012; Wilke et al., 2014). There is no obvious explanation to this toxicity.

\subsubsection{Adverse effects specific to PKIs}

Hepatotoxicity and transaminase increase are common adverse events for many PKIs, such as pazopanib or cabozantinib (Fig. 4). Patients having a transaminase increase with pazopanib that return to grade 1 ( $<3$ times the upper limit of normal) or less could be challenged again with a close monitoring of the liver function (Powles et al., 2015). Concomitant use of statins with pazopanib increases the risk of liver damage (Xu et al., 2012) and is contra-indicated.

PKIs frequently have gastro-intestinal toxicities such as nausea-vomiting or diarrhea (Strumberg et al., 2006) (Fig. 4). A possible role of pancreatic exocrine dysfunction was emphasized and it was proposed to supplement patients having a steatorrhea with pancreatic enzyme supplements (Mir et al., 2012a,b). Skin rash is very frequent with sorafenib, vandetanib, and regorafenib, compatible with the inhibition of the RAF and EGFR pathways (Fig. 3).

Hand-foot syndrome (HFS) is an important toxicity of PKIs which is often dose limiting. With regorafenib, $60 \%$ of patients have an HFS with $20 \%$ of grade 3 (McLellan et al., 2015), and there is a high variability between PKIs (Fig. 4) (Lipworth et al., 2009). Bevacizumab increases the risk of HFS when combined with capecitabine or docetaxel (Gopal et al., 2013). This adverse event seems to be linked with sudation (Lankheet et al., 2013) and is increased during summer, although the role of sweat excretion remains unclear.

Many PKIs can induce myelosuppression, with a different rate of neutropenia or thrombopenia. Sunitinib is the most myelosuppressive AA PKI (Fig. 4).

Destruction of tumor cells itself brings fatigue. However, PKIs have different impact on tiredness. This adverse event is sometimes related to anemia, which needs to be treated properly. An important drug-related fatigue might justify the change of a PKI in renal cancer. Patients using pazopanib have a better quality of life with less fatigue than those using sunitinib, with comparable outcomes (Motzer et al., 2014). Conversely, the association of lenvatinib with everolimus induces a lot of fatigue (73\% all grade, Fig. 4).

Thyroid vasculature is very sensitive to inhibition of VEGF pathway (Kamba et al., 2006). As a result, hypothyroidism is a common side effect of all AA PKIs (Fallahi et al., 2014). The proportion of patients treated for a renal cancer with sunitinib who develop biological and clinical hypothyroidism is higher than $80 \%$ (Rini et al., 2007). Monthly monitoring of TSH and T4 is therefore recommended to initiate levothyroxine substitution as soon as needed (Wolter et al., 2008). Other endocrine dysfunction includes hypophosphatemia, present in $45 \%$ of patients treated with sorafenib for an RCC (Mir et al., 2012a,b). Sorafenib appears to induce steatorrhea due to pancreatic exocrine dysfunction which induces vitamin D malabsorption. Mir suggested that these patients could benefit both vitamin D supplementation and pancreatic enzyme replacement (Mir et al., 2012a,b).

PKIs can also increase QT interval. Vandetanib, in particular, prolongs QTc prolongation by a mean of $36 \mathrm{~ms}$ and the rate of QTc prolongation greater than $60 \mathrm{~ms}$ is $12-15 \%$, with a risk of Torsade de Pointes arrhythmia (Salem et al., 2016; Zamorano et al., 2016). Therefore, this treatment needs a very close monitoring of electrocardiogram and electrolytes. A congenital long QT syndrome should be 
eliminated before treatment initiation. Other PKIs have a milder effect on QTc lengthening but most of them prolong QTc beyond the 5 or even 10 ms cut-off, justifying close ECG monitoring and cardiologic monitoring (Zamorano et al., 2016).

\section{Therapeutic drug monitoring}

\subsection{Pharmacokinetics}

The relationship between exposure and toxicity or efficacy has been demonstrated for some AA PKIs (Bellesoeur et al., 2014; Houk et al., 2010; Pécuchet et al., 2012). Verheijen et al. showed that pazopanib exposure varied greatly in patients treated for mCCRCC or soft tissue sarcoma (Verheijen et al., 2016). They conducted a prospective trial in those populations, with a starting dose of $800 \mathrm{mg}$ OD of pazopanib. Depending on the through plasma concentration (Cmin) of pazopanib and the toxicity of the drug, they allowed either a dose increase or a dose reduction. No patient with a trough concentration $(\mathrm{Cmin})<20$ $\mathrm{mg} / \mathrm{L}$ had a decrease in tumor size, and $20 \mathrm{mg} / \mathrm{L}$ was therefore proposed as a lower plasma concentration threshold.

However, except for imatinib which has been extensively studied the interest of therapeutic drug monitoring (TDM) and target concentration intervention has been poorly investigated for the majority of PKIs in solid cancer. Many oncologists argue that TDM never proved to increase overall survival in a front line trial randomizing patients benefiting from TDM versus patients who did not. Although TDM might not be a convenient method for all patients, some patients have a high risk of inappropriate drug exposure. This includes patients who are obese, who have liver or renal impairment or who experience unexpected toxicity after treatment initiation.

\subsection{Pharmacodynamics}

Although a number of surrogate markers for anti-VEGF-Activity have been investigated, none have been clinically validated as a predictive factor of AA efficacy or toxicity (Jain et al., 2009; Longo and Gasparini, 2007).

\subsubsection{Biological biomarkers}

Circulating VEGF was originally identified as a marker of poor prognosis in various cancers (Poon et al., 2001). However, the baseline level of circulating VEGF-A, failed to prove its usefulness as a predictive biomarker in most AA studies (Dowlati et al., 2008; Murukesh et al., 2010). Other markers, e.g. circulating VEGFR-2 or VEGFR-3, decrease with AA PKIs therapy but have not been shown to be linked to prognosis (Jain et al., 2009).

\subsubsection{Imaging biomarkers}

The modification of vascular permeability and endothelial surface can be measured by Dynamic Contrast-Enhanced Magnetic Resonance Imaging (DCE-MRI). Different permeability parameters such as the transfer constant $\left(\mathrm{K}_{\text {trans }}\right)$ could be measured with this technique, as described by Tofts. $K_{\text {trans }}$ is the permeability surface area product per unit volume of tissue, which is calculated by pharmacokinetic modeling of gadolinium. Under flow-limited conditions $\mathrm{K}_{\text {trans }}$ equals the blood plasma flow per unit volume of tissue (Tofts, 1997; Tofts et al., 1999). $\mathrm{K}_{\text {trans }}$ measurement decreases with tumor vasculature density and a decrease has been described for various cancers with many different angiogenics (Cho et al., 2014; Kim et al., 2014; Li et al., 2015; Marinovich et al., 2012; Messiou et al., 2012; Stacchiotti et al., 2009). Dose-response relationship of this decrease has been shown with some anti-angiogenic investigational drugs (Morgan et al., 2003; Robinson et al., 2003). However, the measurement of $K_{\text {trans }}$ by DCE-MRI after 4 weeks of sorafenib failed to predict an improvement in PFS (Hahn et al., 2008). DCE-MRI can also measure tissue homogeneity. The adiabatic approximation of tissue homogeneity, which is one parameter described by Tofts pharmacokinetic model, could also be an interesting marker: it was predictive of the overall survival for patients treated by sorafenib for a HCC (S. H. Lee et al., 2015).

Dynamic Contrast-Enhanced Ultrasonography (DCE-US) is another method to measure tissue perfusion and can also detect reduction in tumor vascularization (Lassau et al., 2007). The mean transit time of the contrast product measured at day 7 after beginning of the treatment was significantly correlated to the freedom from progression in different tumor types treated with a combination of bevacizumab and chemotherapy (Lassau et al., 2016).

Because some PKIs might induce tumor necrosis without tumor shrinkage, some alternative response criteria other than RECIST 1.1 have been developed (Choi et al., 2007). Choi's criteria for example, adds the tumor density information to classify the tumor in either a response or a progression. For many cancers, alternative criteria have been proposed (Dudeck et al., 2011; Karakiewicz et al., 2016; Krajewski et al., 2011; Schmidt et al., 2013; Veldt et al., 2010). For patients with HCC treated by sorafenib (Ronot et al., 2014), Choi's and modified RECIST (mRECIST) criteria appear more appropriate than RECIST 1.1.

\subsubsection{Clinical biomarkers}

Specific on-target toxicity, such as hypertension, might be a surrogate of VEGF pathway inhibition. Several retrospective studies showed that patients having hypertension had better outcomes (Dahlberg et al., 2010; Rini et al., 2010). However, a meta-analysis by Hurwitz et al. confirmed these results in only one out of seven prospective studies, analyzing hypertension arising within 60 days of AA initiation (Hurwitz et al., 2013). These contrasting results could be explained by the kinetics of hypertension, its intensity, cutoff values or the variety of tumor types which were different between studies. Many other studies later confirmed the prognostic role of hypertension in patients with colorectal cancer and glioblastoma treated with AA as a predictive marker of overall survival (Khoja et al., 2014; Lombardi et al., 2013; Österlund et al., 2011).

The frequency of skin rash and diarrhea which are two sorafenib toxicities are also correlated with better outcomes in advanced solid tumors (Strumberg et al., 2006) and in HCC (Abdel-Rahman and Lamarca, 2017). Similar results were found for neutropenia and sunitinib in RCC (Donskov et al., 2015).

Axitinib is the only AA drug for which an increase in drug intakes is allowed, when no drug toxicity is observed. Axitinib up-titration was associated with increased efficacy in metastatic CCRCC compared to a placebo titration (Rini et al., 2013). Most trials assessing axitinib efficacy were using this dose-escalation strategy (Spano et al., 2008, 2012)

\section{Perspectives}

\subsection{Different targetable pathways}

Besides VEGF/VEGFR pathway, many other pathways contribute to angiogenesis, either initially, or as a resistance mechanism to VEGF/ VEGFR inhibitors (Kerbel, 2008). Those alternative pathways may be new therapeutic targets.

Angiopoietin (ANG) is another family of protein growth factors. Similarly to the binding of VEGF-A to VEGFR-2, ANG1 and ANG2 bind to TIE2, a tyrosine kinase receptor of the endothelial cell membrane (Fig. 2). Trebananib is an example of peptibody that blocks binding of angiopoietin-1 and -2 to Tie2. It is currently under investigation in various cancers. It improves median PFS in ovarian cancer but failed to improve significantly overall survival with concomitant paclitaxel (Monk et al., 2016) or failed to improve PFS with concomitant pegylated liposomal doxorubicin (Marth et al., 2017). FGF/FGFR pathways are other promising angiogenesis targets (Porta et al., 2017; Ronca et al., 2015). Some PKIs already on the market have a FGFR inhibitor activity (cf. Fig. 3), and others are in development. Lucitanib or TAS120, among others, have shown promising activity against FGFR 
mutated breast cancer (Soria et al., 2014) or lung cancer and phase 2 trials are ongoing (NCT02053636, NCT02202746, NCT02109016).

Other currently studied pathways implicated in angiogenesis focus on Transforming Growth Factor- $\beta$, delta/Jagged-Notch and chemokines such as CXC chemokine receptor type 4 (CXCR4)/CXC motif chemokine 12 (CXCL12) signaling (Liang et al., 2007; Salem et al., 2012; Bruix et al., 2017; Kangsamaksin et al., 2015).

\subsection{Mechanisms of resistance}

Four main resistance mechanisms to AA drugs were proposed (Bergers and Hanahan, 2008): activation of alternative angiogenic pathways, recruitment of bone-marrow derived cells which promote angiogenesis, use of pericytes to support the tumor vasculature and finally the promotion of invasion and metastasis.

These resistances, could be reverted by ANG1/Tie2 inhibitors such as regorafenib in HCC (Bruix et al., 2017) or Notch pathway inhibitors, as a second line after currently approved AA (Kangsamaksin et al., 2015).

When PKIs are used to inhibit tumor kinases that are not directly involved in angiogenesis pathways, secondary mutation could also bring resistance to treatment. For example, secondary mutation $D 820 Y$, $D 820 E$, and $N 822 K$ of the tyrosine kinase receptor cKIT in GIST confers secondary resistance to sunitinib (Guo et al., 2009).

Polymorphisms of VEGF rs2010963 (VEGF-A) and rs4604006 (VEGF-C) are associated with poorer prognosis in HCC treated by AA (Scartozzi et al., 2014). It could be hypothesized that a tumor could promote a secondary mutation to the VEGF secreted that could lead to treatment failure.

\section{Conclusion}

Angiogenesis has led to many treatment innovations in oncology and other drugs and combinations are about to come. The VEGF-A/ VEGFR-2 pathway is central to every AA drug that has a significant AA activity. Toxicities of PKIs are strongly related to their spectrum of activity on the kinome. AA therapy used as maintenance seems more effective, particularly in combination with other targeted therapies. Therapeutic drug monitoring should be considered when patients have a high risk of change in its pharmacokinetics properties. Biological, imaging and clinical surrogates might be of some help, although their systemic use for guidance of prescription needs further evidence using rigorous methodology. However, many cancers remain resistant to current AA drugs, and require better understanding and possibly new class of drugs to be efficacious.

\section{Conflicts of interest}

The authors declare they have no conflict of interest.

\section{References}

Österlund, P., Soveri, L.-M., Isoniemi, H., Poussa, T., Alanko, T., Bono, P., 2011 Hypertension and overall survival in metastatic colorectal cancer patients treated with bevacizumab-containing chemotherapy. Br. J. Cancer 104, 599-604. http://dx. doi.org/10.1038/bjc.2011.2.

Abdel-Rahman, O., Lamarca, A., 2017. Development of sorafenib-related side effects in patients diagnosed with advanced hepatocellular carcinoma treated with sorafenib: a systematic-review and meta-analysis of the impact on survival. Expert Rev. Gastroenterol. Hepatol. 11, 75-83. http://dx.doi.org/10.1080/17474124.2017. 1264874.

Abdelaziz, A., Vaishampayan, U., 2017. Cabozantinib for renal cell carcinoma: current and future paradigms. Curr. Treat. Options Oncol. 18, 18. http://dx.doi.org/10. 1007/s11864-017-0444-6.

Abou-Alfa, G.K., Schwartz, L., Ricci, S., Amadori, D., Santoro, A., Figer, A., De Greve, J., Douillard, J.-Y., Lathia, C., Schwartz, B., Taylor, I., Moscovici, M., Saltz, L.B., 2006. Phase II study of sorafenib in patients with advanced hepatocellular carcinoma. J. Clin. Oncol. Off. J. Am. Soc. Clin. Oncol. 24, 4293-4300. http://dx.doi.org/10.1200/ JCO.2005.01.3441.

Abou-Fayçal, C., Hatat, A.-S., Gazzeri, S., Eymin, B., 2017. Splice variants of the RTK family: their role in tumour progression and response to targeted therapy. Int. J. Mol. Sci. 18. http://dx.doi.org/10.3390/ijms18020383.

Adrian, G., Marcel, V., Robert, B., Richard, T., 2007. A comparison of physicochemical property profiles of marketed oral drugs and orally bioavailable anti-cancer protein kinase inhibitors in clinical development. Curr. Top. Med. Chem. 7, 1408-1422. http://dx.doi.org/10.2174/156802607781696819.

Beedie, S.L., Mahony, C., Walker, H.M., Chau, C.H., Figg, W.D., Vargesson, N., 2016. Shared mechanism of teratogenicity of anti-angiogenic drugs identified in the chicken embryo model. Sci. Rep. 6, 30038. http://dx.doi.org/10.1038/srep30038.

Bellesoeur, A., Carton, E., Mir, O., Groussin, L., Blanchet, B., Billemont, B., Clerc, J., Goldwasser, F., 2014. Critical role of sorafenib exposure over time for its antitumor activity in thyroid cancer. Invest. New Drugs 32, 569-572. http://dx.doi.org/10. 1007/s10637-013-0052-7.

Bergers, G., Hanahan, D., 2008. Modes of resistance to anti-angiogenic therapy. Nat. Rev. Cancer 8, 592-603. http://dx.doi.org/10.1038/nrc2442.

Bergh, J., Bondarenko, I.M., Lichinitser, M.R., Liljegren, A., Greil, R., Voytko, N.L., Makhson, A.N., Cortes, J., Lortholary, A., Bischoff, J., Chan, A., Delaloge, S., Huang, X., Kern, K.A., Giorgetti, C., 2012. First-line treatment of advanced breast cancer with sunitinib in combination with docetaxel versus docetaxel alone: results of a prospective, randomized phase III study. J. Clin. Oncol. Off. J. Am. Soc. Clin. Oncol. 30, 921-929. http://dx.doi.org/10.1200/JCO.2011.35.7376.

Biziota, E., Mavroeidis, L., Hatzimichael, E., Pappas, P., 2017. Metronomic chemotherapy: a potent macerator of cancer by inducing angiogenesis suppression and antitumor immune activation. Cancer Lett. 400, 243-251. http://dx.doi.org/10. 1016/j.canlet.2016.12.018.

Bruix, J., Qin, S., Merle, P., Granito, A., Huang, Y.-H., Bodoky, G., Pracht, M., Yokosuka, O., Rosmorduc, O., Breder, V., Gerolami, R., Masi, G., Ross, P.J., Song, T., Bronowicki, J.-P., Ollivier-Hourmand, I., Kudo, M., Cheng, A.-L., Llovet, J.M., Finn, R.S., LeBerre, M.-A., Baumhauer, A., Meinhardt, G., Han, G., Resorce Investigators, 2017. Regorafenib for patients with hepatocellular carcinoma who progressed on sorafenib treatment (RESORCE): a randomised, double-blind, placebo-controlled, phase 3 trial. Lancet Lond. Engl. 389, 56-66. http://dx.doi.org/10.1016/S01406736(16)32453-9.

Bunn, P.A., Franklin, W., 2002. Epidermal growth factor receptor expression, signal pathway, and inhibitors in non-small cell lung cancer. Semin. Oncol. 29, 38-44. http://dx.doi.org/10.1053/sonc.2002.35646.

Cébe Suarez, S., Pieren, M., Cariolat, L., Arn, S., Hoffmann, U., Bogucki, A., Manlius, C., Wood, J., Ballmer-Hofer, K., 2006. A VEGF-A splice variant defective for heparan sulfate and neuropilin-1 binding shows attenuated signaling through VEGFR-2. Cell. Mol. Life Sci. CMLS 63, 2067-2077. http://dx.doi.org/10.1007/s00018-006-6254-9.

Cameron, D., Brown, J., Dent, R., Jackisch, C., Mackey, J., Pivot, X., Steger, G.G., Suter, T.M., Toi, M., Parmar, M., Laeufle, R., Im, Y.-H., Romieu, G., Harvey, V., Lipatov, O., Pienkowski, T., Cottu, P., Chan, A., Im, S.-A., Hall, P.S., Bubuteishvili-Pacaud, L., Henschel, V., Deurloo, R.J., Pallaud, C., Bell, R., 2013. Adjuvant bevacizumab-containing therapy in triple-negative breast cancer (BEATRICE): primary results of a randomised, phase 3 trial. Lancet Oncol. 14, 933-942. http://dx.doi.org/10.1016/ S1470-2045(13)70335-8.

Carrato, A., Swieboda-Sadlej, A., Staszewska-Skurczynska, M., Lim, R., Roman, L., Shparyk, Y., Bondarenko, I., Jonker, D.J., Sun, Y., De la Cruz, J.A., Williams, J.A., Korytowsky, B., Christensen, J.G., Lin, X., Tursi, J.M., Lechuga, M.J., Van Cutsem, E., 2013. Fluorouracil, leucovorin, and irinotecan plus either sunitinib or placebo in metastatic colorectal cancer: a randomized, phase III trial. J. Clin. Oncol. Off. J. Am. Soc. Clin. Oncol. 31, 1341-1347. http://dx.doi.org/10.1200/JCO.2012.45.1930.

Caulet, M., Lecomte, T., Bouché, O., Rollin, J., Gouilleux-Gruart, V., Azzopardi, N., Léger, J., Borg, C., Douillard, J.-Y., Manfredi, S., Smith, D., Capitain, O., Ferru, A., Moussata, D., Terrebone, E., Paintaud, G., Ternant, D., 2016. Bevacizumab pharmacokinetics influence overall and progression-free survival in metastatic colorectal cancer patients. Clin. Pharmacokinet. 55, 1381-1394. http://dx.doi.org/10.1007/s40262-0160406-3.

Chelis, L., Souftas, V., Amarantidis, K., Xenidis, N., Chamalidou, E., Dimopoulos, P., Michailidis, P., Christakidis, E., Prassopoulos, P., Kakolyris, S., 2012. Reversible posterior leukoencephalopathy syndrome induced by pazopanib. BMC Cancer 12, 489. http://dx.doi.org/10.1186/1471-2407-12-489.

Chen, H., Modiano, M.R., Neal, J.W., Brahmer, J.R., Rigas, J.R., Jotte, R.M., Leighl, N.B., Riess, J.W., Kuo, C.J., Liu, L., Gao, B., Dicioccio, A.T., Adjei, A.A., Wakelee, H.A., 2014. A phase II multicentre study of ziv-aflibercept in combination with cisplatin and pemetrexed in patients with previously untreated advanced/metastatic nonsquamous non-small cell lung cancer. Br. J. Cancer 110, 602-608. http://dx.doi.org/ 10.1038/bjc. 2013.735.

Cho, N., Im, S.-A., Park, I.-A., Lee, K.-H., Li, M., Han, W., Noh, D.-Y., Moon, W.K., 2014. Breast cancer: early prediction of response to neoadjuvant chemotherapy using parametric response maps for MR imaging. Radiology 272, 385-396. http://dx.doi. org/10.1148/radiol.14131332.

Choi, H., Charnsangavej, C., Faria, S.C., Macapinlac, H.A., Burgess, M.A., Patel, S.R., Chen, L.L., Podoloff, D.A., Benjamin, R.S., 2007. Correlation of computed tomography and positron emission tomography in patients with metastatic gastrointestinal stromal tumor treated at a single institution with imatinib mesylate: proposal of new computed tomography response criteria. J. Clin. Oncol. Off. J. Am. Soc. Clin. Oncol. 25, 1753-1759. http://dx.doi.org/10.1200/jco.2006.07.3049.

Choueiri, T.K., Escudier, B., Powles, T., Tannir, N.M., Mainwaring, P.N., Rini, B.I., Hammers, H.J., Donskov, F., Roth, B.J., Peltola, K., Lee, J.L., Heng, D.Y.C., Schmidinger, M., Agarwal, N., Sternberg, C.N., McDermott, D.F., Aftab, D.T., Hessel, C., Scheffold, C., Schwab, G., Hutson, T.E., Pal, S., Motzer, R.J., METEOR investigators, 2016. Cabozantinib versus everolimus in advanced renal cell carcinoma (METEOR): final results from a randomised, open-label, phase 3 trial. Lancet Oncol. 17, 917-927. http://dx.doi.org/10.1016/s1470-2045(16)30107-3. 
Choueiri, T.K., Halabi, S., Sanford, B.L., Hahn, O., Michaelson, M.D., Walsh, M.K., Feldman, D.R., Olencki, T., Picus, J., Small, E.J., Dakhil, S., George, D.J., Morris, M.J., 2017. Cabozantinib versus sunitinib as initial targeted therapy for patients with metastatic renal cell carcinoma of poor or intermediate risk: the alliance A031203 CABOSUN trial. J. Clin. Oncol. Off. J. Am. Soc. Clin. Oncol. 35, 591-597. http://dx doi.org/10.1200/JCO.2016.70.7398.

Christodoulou, C., Pervena, A., Klouvas, G., Galani, E., Falagas, M.E., Tsakalos, G., Visvikis, A., Nikolakopoulou, A., Acholos, V., Karapanagiotidis, G., Batziou, E., Skarlos, D.V., 2009. Combination of bisphosphonates and antiangiogenic factors in duces osteonecrosis of the jaw more frequently than bisphosphonates alone. Oncology 76, 209-211. http://dx.doi.org/10.1159/000201931.

Crown, J.P., Diéras, V., Staroslawska, E., Yardley, D.A., Bachelot, T., Davidson, N., Wildiers, H., Fasching, P.A., Capitain, O., Ramos, M., Greil, R., Cognetti, F., Fountzilas, G., Blasinska-Morawiec, M., Liedtke, C., Kreienberg, R., Miller, W.H., Tassell, V., Huang, X., Paolini, J., Kern, K.A., Romieu, G., 2013. Phase III trial of sunitinib in combination with capecitabine versus capecitabine monotherapy for the treatment of patients with pretreated metastatic breast cancer. J. Clin. Oncol. Off. J. Am. Soc. Clin. Oncol. 31, 2870-2878. http://dx.doi.org/10.1200/jco.2012.43.3391.

Cumurciuc, R., Martinez-Almoyna, L., Henry, C., Husson, H., de Broucker, T., 2008. Posterior reversible encephalopathy syndrome during sunitinib therapy. Rev. Neurol. (Paris) 164, 605-607. http://dx.doi.org/10.1016/j.neurol.2008.03.007.

Dahlberg, S.E., Sandler, A.B., Brahmer, J.R., Schiller, J.H., Johnson, D.H., 2010. Clinical course of advanced non-small-cell lung cancer patients experiencing hypertension during treatment with bevacizumab in combination with carboplatin and paclitaxel on ECOG 4599. J. Clin. Oncol. Off. J. Am. Soc. Clin. Oncol. 28, 949-954. http://dx. doi.org/10.1200/JCO.2009.25.4482.

Davis, M.I., Hunt, J.P., Herrgard, S., Ciceri, P., Wodicka, L.M., Pallares, G., Hocker, M., Treiber, D.K., Zarrinkar, P.P., 2011. Comprehensive analysis of kinase inhibitor selectivity. Nat. Biotechnol. 29, 1046-1051. http://dx.doi.org/10.1038/nbt.1990.

Demetri, G.D., van Oosterom, A.T., Garrett, C.R., Blackstein, M.E., Shah, M.H., Verweij, J., McArthur, G., Judson, I.R., Heinrich, M.C., Morgan, J.A., Desai, J., Fletcher, C.D., George, S., Bello, C.L., Huang, X., Baum, C.M., Casali, P.G., 2006. Efficacy and safety of sunitinib in patients with advanced gastrointestinal stromal tumour after failure of imatinib: a randomised controlled trial. Lancet Lond. Engl. 368, 1329-1338. http:// dx.doi.org/10.1016/s0140-6736(06)69446-4.

Demetri, G.D., Reichardt, P., Kang, Y.-K., Blay, J.-Y., Rutkowski, P., Gelderblom, H., Hohenberger, P., Leahy, M., von Mehren, M., Joensuu, H., Badalamenti, G., Blackstein, M., Le Cesne, A., Schöffski, P., Maki, R.G., Bauer, S., Nguyen, B.B., Xu, J., Nishida, T., Chung, J., Kappeler, C., Kuss, I., Laurent, D., Casali, P.G., GRID study investigators, 2013. Efficacy and safety of regorafenib for advanced gastrointestinal stromal tumours after failure of imatinib and sunitinib (GRID): an international, multicentre, randomised, placebo-controlled, phase 3 trial. Lancet Lond. Engl. 381, 295-302. http://dx.doi.org/10.1016/s0140-6736(12)61857-1.

Desar, I.M.E., Burger, D.M., Van Hoesel, Q.G.C.M., Beijnen, J.H., Van Herpen, C.M.L., Van der Graaf, W.T.A., 2009. Pharmacokinetics of sunitinib in an obese patient with a GIST. Ann. Oncol. Off. J. Eur. Soc. Med. Oncol. 20, 599-600. http://dx.doi.org/10. 1093/annonc/mdn779.

Diekstra, M.H.M., Klümpen, H.J., Lolkema, M.P.J.K., Yu, H., Kloth, J.S.L., Gelderblom, H., van Schaik, R.H.N., Gurney, H., Swen, J.J., Huitema, A.D.R., Steeghs, N., Mathijssen, R.H.J., 2014. Association analysis of genetic polymorphisms in genes related to sunitinib pharmacokinetics, specifically clearance of sunitinib and SU12662. Clin. Pharmacol. Ther. 96, 81-89. http://dx.doi.org/10.1038/clpt.2014.47.

Donskov, F., Michaelson, M.D., Puzanov, I., Davis, M.P., Bjarnason, G.A., Motzer, R.J., Goldstein, D., Lin, X., Cohen, D.P., Wiltshire, R., Rini, B.I., 2015. Sunitinib-associated hypertension and neutropenia as efficacy biomarkers in metastatic renal cell carcinoma patients. Br. J. Cancer 113, 1571-1580. http://dx.doi.org/10.1038/bjc.2015 368.

Dowlati, A., Gray, R., Sandler, A.B., Schiller, J.H., Johnson, D.H., 2008. Cell adhesion molecules, vascular endothelial growth factor, and basic fibroblast growth factor in patients with non-small cell lung cancer treated with chemotherapy with or without bevacizumab-an Eastern Cooperative Oncology Group Study. Clin. Cancer Res. Off. J. Am. Assoc. Cancer Res. 14, 1407-1412. http://dx.doi.org/10.1158/1078-0432.ccr07-1154.

Dudeck, O., Zeile, M., Reichardt, P., Pink, D., 2011. Comparison of RECIST and Choi criteria for computed tomographic response evaluation in patients with advanced gastrointestinal stromal tumor treated with sunitinib. Ann. Oncol. Off. J. Eur. Soc. Med. Oncol. 22, 1828-1833. http://dx.doi.org/10.1093/annonc/mdq696.

de Groot, J.W.B., Links, T.P., van der Graaf, W.T.A., 2006. Tyrosine kinase inhibitors causing hypothyroidism in a patient on levothyroxine. Ann. Oncol. Off. J. Eur. Soc. Med. Oncol. 17, 1719-1720. http://dx.doi.org/10.1093/annonc/mdl112.

de Jesus-Gonzalez, N., Robinson, E., Moslehi, J., Humphreys, B.D., 2012. Management of antiangiogenic therapy-induced hypertension. Hypertens. Dallas Tex. 1979 (60), 607-615. http://dx.doi.org/10.1161/HYPERTENSIONAHA.112.196774.

Elisei, R., Schlumberger, M.J., Müller, S.P., Schöffski, P., Brose, M.S., Shah, M.H., Licitra, L., Jarzab, B., Medvedev, V., Kreissl, M.C., Niederle, B., Cohen, E.E.W., Wirth, L.J. Ali, H., Hessel, C., Yaron, Y., Ball, D., Nelkin, B., Sherman, S.I., 2013. Cabozantinib in progressive medullary thyroid cancer. J. Clin. Oncol. Off. J. Am. Soc. Clin. Oncol. 31, 3639-3646. http://dx.doi.org/10.1200/JCO.2012.48.4659.

Erdem, L., Giovannetti, E., Leon, L.G., Honeywell, R., Peters, G.J., 2012. Polymorphisms to predict outcome to the tyrosine kinase inhibitors gefitinib, erlotinib, sorafenib and sunitinib. Curr. Top. Med. Chem. 12, 1649-1659.

Eremina, V., Jefferson, J.A., Kowalewska, J., Hochster, H., Haas, M., Weisstuch, J., Richardson, C., Kopp, J.B., Kabir, M.G., Backx, P.H., Gerber, H.-P., Ferrara, N., Barisoni, L., Alpers, C.E., Quaggin, S.E., 2008. VEGF inhibition and renal thrombotic microangiopathy. N. Engl. J. Med. 358, 1129-1136. http://dx.doi.org/10.1056/ NEJMoa0707330.
Escudier, B., Eisen, T., Stadler, W.M., Szczylik, C., Oudard, S., Siebels, M., Negrier, S. Chevreau, C., Solska, E., Desai, A.A., Rolland, F., Demkow, T., Hutson, T.E., Gore, M., Freeman, S., Schwartz, B., Shan, M., Simantov, R., Bukowski, R.M., TARGET Study Group, 2007a. Sorafenib in advanced clear-cell renal-cell carcinoma. N. Engl. J. Med. 356, 125-134. http://dx.doi.org/10.1056/NEJMoa060655.

Escudier, B., Pluzanska, A., Koralewski, P., Ravaud, A., Bracarda, S., Szczylik, C., Chevreau, C., Filipek, M., Melichar, B., Bajetta, E., Gorbunova, V., Bay, J.-O., Bodrogi, I., Jagiello-Gruszfeld, A., Moore, N., AVOREN Trial investigators, 2007b. Bevacizumab plus interferon alfa-2a for treatment of metastatic renal cell carcinoma: a randomised, double-blind phase III trial. Lancet Lond. Engl. 370, 2103-2111. http://dx.doi.org/10.1016/s0140-6736(07)61904-7.

Escudier, B., Roigas, J., Gillessen, S., Harmenberg, U., Srinivas, S., Mulder, S.F., Fountzilas, G., Peschel, C., Flodgren, P., Maneval, E.C., Chen, I., Vogelzang, N.J., 2009. Phase II study of sunitinib administered in a continuous once-daily dosing regimen in patients with cytokine-refractory metastatic renal cell carcinoma. J. Clin. Oncol. Off. J. Am. Soc. Clin. Oncol. 27, 4068-4075. http://dx.doi.org/10.1200/jco. 2008.20.5476

Escudier, B., Porta, C., Bono, P., Powles, T., Eisen, T., Sternberg, C.N., Gschwend, J.E., De Giorgi, U., Parikh, O., Hawkins, R., Sevin, E., Négrier, S., Khan, S., Diaz, J., Redhu, S. Mehmud, F., Cella, D., 2014. Randomized, controlled, double-blind, cross-over trial assessing treatment preference for pazopanib versus sunitinib in patients with metastatic renal cell carcinoma: PISCES Study. J. Clin. Oncol. Off. J. Am. Soc. Clin. Oncol. 32, 1412-1418. http://dx.doi.org/10.1200/JCO.2013.50.8267.

Fallahi, P., Ferrari, S.M., Vita, R., Di Domenicantonio, A., Corrado, A., Benvenga, S., Antonelli, A., 2014. Thyroid dysfunctions induced by tyrosine kinase inhibitors. Expert Opin. Drug Saf. 13, 723-733. http://dx.doi.org/10.1517/14740338.2014. 913021.

Flaherty, K.T., Lee, S.J., Zhao, F., Schuchter, L.M., Flaherty, L., Kefford, R., Atkins, M.B., Leming, P., Kirkwood, J.M., 2013. Phase III trial of carboplatin and paclitaxel with or without sorafenib in metastatic melanoma. J. Clin. Oncol. Off. J. Am. Soc. Clin. Oncol. 31, 373-379. http://dx.doi.org/10.1200/JCO.2012.42.1529.

Folkman, J., Merler, E., Abernathy, C., Williams, G., 1971. Isolation of a tumor factor responsible for angiogenesis. J. Exp. Med. 133, 275-288.

Frew, I.J., Moch, H., 2015. A clearer view of the molecular complexity of clear cell renal cell carcinoma. Annu. Rev. Pathol. 10, 263-289. http://dx.doi.org/10.1146/ annurev-pathol-012414-040306.

Ge, J., Tan, B.-X., Chen, Y., Yang, L., Peng, X.-C., Li, H.-Z., Lin, H.-J., Zhao, Y., Wei, M., Cheng, K., Li, L.-H., Dong, H., Gao, F., He, J.-P., Wu, Y., Qiu, M., Zhao, Y.-L., Su, J.M., Hou, J.-M., Liu, J.-Y., 2011. Interaction of green tea polyphenol epigallocatechin3-gallate with sunitinib: potential risk of diminished sunitinib bioavailability. J. Mol. Med. Berl. Ger. 89, 595-602. http://dx.doi.org/10.1007/s00109-011-0737-3.

Ghatalia, P., Morgan, C.J., Je, Y., Nguyen, P.L., Trinh, Q.-D., Choueiri, T.K., Sonpavde, G., 2015. Congestive heart failure with vascular endothelial growth factor receptor tyrosine kinase inhibitors. Crit. Rev. Oncol. Hematol. 94, 228-237. http://dx.doi.org/ 10.1016/j.critrevonc.2014.12.008.

Gilbert, M.R., Dignam, J.J., Armstrong, T.S., Wefel, J.S., Blumenthal, D.T., Vogelbaum, M.A., Colman, H., Chakravarti, A., Pugh, S., Won, M., Jeraj, R., Brown, P.D., Jaeckle, K.A., Schiff, D., Stieber, V.W., Brachman, D.G., Werner-Wasik, M., Tremont-Lukats, I.W., Sulman, E.P., Aldape, K.D., Curran, W.J.J., Mehta, M.P., 2014. A randomized trial of bevacizumab for newly diagnosed glioblastoma. N. Engl. J. Med. 370, 699-708. http://dx.doi.org/10.1056/NEJMoa1308573.

Gonçalves, A., Gilabert, M., François, E., Dahan, L., Perrier, H., Lamy, R., Re, D., Largillier, R., Gasmi, M., Tchiknavorian, X., Esterni, B., Genre, D., Moureau-Zabotto, L., Giovannini, M., Seitz, J.-F., Delpero, J.-R., Turrini, O., Viens, P., Raoul, J.-L., 2012. BAYPAN study: a double-blind phase III randomized trial comparing gemcitabine plus sorafenib and gemcitabine plus placebo in patients with advanced pancreatic cancer. Ann. Oncol. Off. J. Eur. Soc. Med. Oncol. 23, 2799-2805. http://dx.doi.org/ 10.1093/annonc/mds135.

Gopal, A., Flores, R.A., Lacouture, M.E., Wu, S., 2013. Differential effects of bevacizumab on the risk of hand-foot syndrome associated with cytotoxic chemotherapy: an updated meta-analysis. J. Clin. Oncol. 31.

Grothey, A., Van Cutsem, E., Sobrero, A., Siena, S., Falcone, A., Ychou, M., Humblet, Y., Bouché, O., Mineur, L., Barone, C., Adenis, A., Tabernero, J., Yoshino, T., Lenz, H.-J., Goldberg, R.M., Sargent, D.J., Cihon, F., Cupit, L., Wagner, A., Laurent, D., CORRECT Study Group, 2013. Regorafenib monotherapy for previously treated metastatic colorectal cancer (CORRECT): an international, multicentre, randomised, placebocontrolled, phase 3 trial. Lancet Lond. Engl. 381, 303-312. http://dx.doi.org/10. 1016/S0140-6736(12)61900-X.

Guan, M., Zhou, Y.-P., Sun, J.-L., Chen, S.-C., 2015. 2015: Adverse events of monoclonal antibodies used for cancer therapy. BioMed. Res. Int. 42816, 9. http://dx.doi.org/10. $1155 / 2015 / 428169$.

Guo, T., Hajdu, M., Agaram, N.P., Shinoda, H., Veach, D., Clarkson, B.D., Maki, R.G., Singer, S., Dematteo, R.P., Besmer, P., Antonescu, C.R., 2009. Mechanisms of sunitinib resistance in gastrointestinal stromal tumors harboring KITAY502-3ins mutation: an in vitro mutagenesis screen for drug resistance. Clin. Cancer Res. Off. J. Am. Assoc. Cancer Res. 15, 6862-6870. http://dx.doi.org/10.1158/1078-0432. (CCR-091315).

Hadj, J.O., Braven, R.D., Tillier, C., Schrijver, H.M., Verheul, H.M.W., VAN DER Vliet, H.J., 2012. Reversible posterior leukoencephalopathy syndrome during sunitinib therapy for metastatic renal cell carcinoma. Oncol. Lett. 3, 1293-1296. http://dx.doi. org $/ 10.3892 / 01.2012 .646$

Hahn, O.M., Yang, C., Medved, M., Karczmar, G., Kistner, E., Karrison, T., Manchen, E., Mitchell, M., Ratain, M.J., Stadler, W.M., 2008. Dynamic contrast-enhanced magnetic resonance imaging pharmacodynamic biomarker study of sorafenib in metastatic renal carcinoma. J. Clin. Oncol. Off. J. Am. Soc. Clin. Oncol. 26, 4572-4578. http:// dx.doi.org/10.1200/JCO.2007.15.5655. 
Han, K., Jin, J., Maia, M., Lowe, J., Sersch, M.A., Allison, D.E., 2014. Lower exposure and faster clearance of bevacizumab in gastric cancer and the impact of patient variables: analysis of individual data from AVAGAST phase III trial. AAPS J. 16, 1056-1063. http://dx.doi.org/10.1208/s12248-014-9631-6.

Han, K., Peyret, T., Marchand, M., Quartino, A., Gosselin, N.H., Girish, S., Allison, D.E., Jin, J., 2016. Population pharmacokinetics of bevacizumab in cancer patients with external validation. Cancer Chemother. Pharmacol. 78, 341-351. http://dx.doi.org/ 10.1007/s00280-016-3079-6.

Hanahan, D., Folkman, J., 1996. Patterns and emerging mechanisms of the angiogenic switch during tumorigenesis. Cell 86, 353-364.

Hanahan, D., Weinberg, R.A., 2000. The hallmarks of cancer. Cell 100, 57-70.

Hapani, S., Sher, A., Chu, D., Wu, S., 2010. Increased risk of serious hemorrhage with bevacizumab in cancer patients: a meta-analysis. Oncology 79, 27-38. http://dx.doi. org $/ 10.1159 / 000314980$.

Hauschild, A., Agarwala, S.S., Trefzer, U., Hogg, D., Robert, C., Hersey, P., Eggermont, A., Grabbe, S., Gonzalez, R., Gille, J., Peschel, C., Schadendorf, D., Garbe, C., O'Day, S., Daud, A., White, J.M., Xia, C., Patel, K., Kirkwood, J.M., Keilholz, U., 2009. Results of a phase III, randomized, placebo-controlled study of sorafenib in combination with carboplatin and paclitaxel as second-line treatment in patients with unresectable stage III or stage IV melanoma. J. Clin. Oncol. Off. J. Am. Soc. Clin. Oncol. 27, 2823-2830. http://dx.doi.org/10.1200/jco.2007.15.7636.

Heinemann, V., von Weikersthal, L.F., Decker, T., Kiani, A., Vehling-Kaiser, U., Al-Batran, S.-E., Heintges, T., Lerchenmüller, C., Kahl, C., Seipelt, G., Kullmann, F., Stauch, M., Scheithauer, W., Hielscher, J., Scholz, M., Müller, S., Link, H., Niederle, N., Rost, A., Höffkes, H.-G., Moehler, M., Lindig, R.U., Modest, D.P., Rossius, L., Kirchner, T. Jung, A., Stintzing, S., 2014. FOLFIRI plus cetuximab versus FOLFIRI plus bevacizumab as first-line treatment for patients with metastatic colorectal cancer (FIRE3): a randomised, open-label, phase 3 trial. Lancet Oncol. 15, 1065-1075. http://dx. doi.org/10.1016/s1470-2045(14)70330-4.

Herbrink, M., Nuijen, B., Schellens, J.H.M., Beijnen, J.H., 2015. Variability in bioavailability of small molecular tyrosine kinase inhibitors. Cancer Treat. Rev. 41, 412-422. http://dx.doi.org/10.1016/j.ctrv.2015.03.005.

Hicklin, D.J., Ellis, L.M., 2005. Role of the vascular endothelial growth factor pathway in tumor growth and angiogenesis. J. Clin. Oncol. Off. J. Am. Soc. Clin. Oncol. 23, 1011-1027. http://dx.doi.org/10.1200/JCO.2005.06.081.

Hilger, R.A., Richly, H., Grubert, M., Kredtke, S., Thyssen, D., Eberhardt, W., Hense, J., Schuler, M., Scheulen, M.E., 2009. Pharmacokinetics of sorafenib in patients with renal impairment undergoing hemodialysis. Int. J. Clin. Pharmacol. Ther. 47, 61-64.

Holash, J., Davis, S., Papadopoulos, N., Croll, S.D., Ho, L., Russell, M., Boland, P., Leidich, R., Hylton, D., Burova, E., Ioffe, E., Huang, T., Radziejewski, C., Bailey, K., Fandl, J.P., Daly, T., Wiegand, S.J., Yancopoulos, G.D., Rudge, J.S., 2002. VEGF-Trap: a VEGF blocker with potent antitumor effects. Proc. Natl. Acad. Sci. U. S. A. 99 11393-11398. http://dx.doi.org/10.1073/pnas.172398299.

Houk, B.E., Bello, C.L., Poland, B., Rosen, L.S., Demetri, G.D., Motzer, R.J., 2010. Relationship between exposure to sunitinib and efficacy and tolerability endpoints in patients with cancer: results of a pharmacokinetic/pharmacodynamic meta-analysis. Cancer Chemother. Pharmacol. 66, 357-371. http://dx.doi.org/10.1007/s00280009-1170-y.

Hurwitz, H., Fehrenbacher, L., Novotny, W., Cartwright, T., Hainsworth, J., Heim, W. Berlin, J., Baron, A., Griffing, S., Holmgren, E., Ferrara, N., Fyfe, G., Rogers, B., Ross, R., Kabbinavar, F., 2004. Bevacizumab plus irinotecan, fluorouracil, and leucovorin for metastatic colorectal cancer. N. Engl. J. Med. 350, 2335-2342. http://dx.doi.org/ 10.1056/NEJMoa032691.

Hurwitz, H.I., Saltz, L.B., Van Cutsem, E., Cassidy, J., Wiedemann, J., Sirzén, F., Lyman, G.H., Rohr, U.-P., 2011. Venous thromboembolic events with chemotherapy plus bevacizumab: a pooled analysis of patients in randomized phase II and III studies. J. Clin. Oncol. Off. J. Am. Soc. Clin. Oncol. 29, 1757-1764. http://dx.doi.org/10.1200/ jco.2010.32.3220.

Hurwitz, H.I., Tebbutt, N.C., Kabbinavar, F., Giantonio, B.J., Guan, Z.-Z., Mitchell, L., Waterkamp, D., Tabernero, J., 2013. Efficacy and safety of bevacizumab in metastatic colorectal cancer: pooled analysis from seven randomized controlled trials. Oncologist 18, 1004-1012. http://dx.doi.org/10.1634/theoncologist.2013-0107.

Hutson, T.E., Davis, I.D., Machiels, J.-P.H., De Souza, P.L., Rottey, S., Hong, B.-F., Epstein, R.J., Baker, K.L., McCann, L., Crofts, T., Pandite, L., Figlin, R.A., 2010. Efficacy and safety of pazopanib in patients with metastatic renal cell carcinoma. J. Clin. Oncol. Off. J. Am. Soc. Clin. Oncol. 28, 475-480. http://dx.doi.org/10.1200/jco.2008.21. 6994.

Izzedine, H., Massard, C., Spano, J.P., Goldwasser, F., Khayat, D., Soria, J.C., 2010. VEGF signalling inhibition-induced proteinuria: mechanisms, significance and management. Eur. J. Cancer Oxf. Engl. 1990 (46), 439-448. http://dx.doi.org/10.1016/j. ejca.2009.11.001.

Jain, R.K., Duda, D.G., Willett, C.G., Sahani, D.V., Zhu, A.X., Loeffler, J.S., Batchelor, T.T., Sorensen, A.G., 2009. Biomarkers of response and resistance to antiangiogenic therapy. Nat. Rev. Clin. Oncol. 6, 327-338. http://dx.doi.org/10.1038/nrclinonc 2009.63.

Jain, R.K., 2005. Normalization of tumor vasculature: an emerging concept in antiangiogenic therapy. Science 307, 58-62. http://dx.doi.org/10.1126/science. 1104819.

Jean, G.W., Mani, R.M., Jaffry, A., Khan, S.A., 2016. Toxic effects of sorafenib in patients with differentiated thyroid carcinoma compared with other cancers. JAMA Oncol. 2, 529-534. http://dx.doi.org/10.1001/jamaoncol.2015.5927.

Josephs, D., Hutson, T.E., Cowey, C.L., Pickering, L.M., Larkin, J.M., Gore, M.E., Van Hemelrijck, M., McDermott, D.F., Powles, T., Chowdhury, P., Karapetis, C., Harper, P.G., Choueiri, T.K., Chowdhury, S., 2011. Efficacy and toxicity of sunitinib in patients with metastatic renal cell carcinoma with severe renal impairment or on haemodialysis. BJU Int. 108, 1279-1283. http://dx.doi.org/10.1111/j.1464-410x. 2010.09990.x.

Kabbinavar, F., Hurwitz, H.I., Fehrenbacher, L., Meropol, N.J., Novotny, W.F., Lieberman, G., Griffing, S., Bergsland, E., 2003. Phase II, randomized trial comparing bevacizumab plus fluorouracil (FU)/leucovorin (LV) with FU/LV alone in patients with metastatic colorectal cancer. J. Clin. Oncol. Off. J. Am. Soc. Clin. Oncol. 21, 60-65. http://dx.doi.org/10.1200/jco.2003.10.066.

Kamba, T., Tam, B.Y.Y., Hashizume, H., Haskell, A., Sennino, B., Mancuso, M.R., Norberg, S.M., O’Brien, S.M., Davis, R.B., Gowen, L.C., Anderson, K.D., Thurston, G., Joho, S., Springer, M.L., Kuo, C.J., McDonald, D.M., 2006. VEGF-dependent plasticity of fenestrated capillaries in the normal adult microvasculature. Am. J. Physiol. Heart Circ. Physiol. 290, H560-576. http://dx.doi.org/10.1152/ajpheart.00133.2005.

Kangsamaksin, T., Murtomaki, A., Kofler, N.M., Cuervo, H., Chaudhri, R.A., Tattersall, I.W., Rosenstiel, P.E., Shawber, C.J., Kitajewski, J., 2015. NOTCH decoys that selectively block DLL/NOTCH or JAG/NOTCH disrupt angiogenesis by unique mechanisms to inhibit tumor growth. Cancer Discov. 5, 182-197. http://dx.doi.org/10. 1158/2159-8290. (CD-14-0650).

Karakiewicz, P.I., Nott, L., Joshi, A., Kannourakis, G., Tarazi, J., Alam, M., 2016. Evaluation of response from axitinib per Response Evaluation Criteria in Solid Tumors versus Choi criteria in previously treated patients with metastatic renal cell carcinoma. OncoTargets Ther. 9, 2855-2863. http://dx.doi.org/10.2147/ott. s102578.

Keizer, R.J., Huitema, A.D.R., Schellens, J.H.M., Beijnen, J.H., 2010. Clinical pharmacokinetics of therapeutic monoclonal antibodies. Clin. Pharmacokinet. 49, 493-507. http://dx.doi.org/10.2165/11531280-000000000-00000.

Kerbel, R.S., 2008. Tumor angiogenesis. N. Engl. J. Med. 358, 2039-2049. http://dx.doi. org/10.1056/NEJMra0706596.

Khoja, L., Kumaran, G., Zee, Y.K., Murukesh, N., Swindell, R., Saunders, M.P., Clamp, A.R., Valle, J.W., Wilson, G., Jayson, G.C., Hasan, J., 2014. Evaluation of hypertension and proteinuria as markers of efficacy in antiangiogenic therapy for metastatic colorectal cancer. J. Clin. Gastroenterol. 48, 430-434. http://dx.doi.org/10.1097/ MCG.0b013e3182a8804c.

Khosravan, R., Toh, M., Garrett, M., La Fargue, J., Ni, G., Marbury, T.C., Swan, S.K., Lunde, N.M., Bello, C.L., 2010. Pharmacokinetics and safety of sunitinib malate in subjects with impaired renal function. J. Clin. Pharmacol. 50, 472-481. http://dx doi.org/10.1177/0091270009347868.

Kim, H.R., Park, H.S., Kwon, W.S., Lee, J.H., Tanigawara, Y., Lim, S.M., Kim, H.S., Shin, S.J., Ahn, J.B., Rha, S.Y., 2013. Pharmacogenetic determinants associated with sunitinib-induced toxicity and ethnic difference in Korean metastatic renal cell carcinoma patients. Cancer Chemother. Pharmacol. 72, 825-835. http://dx.doi.org/10. 1007/s00280-013-2258-y.

Kim, H., Keene, K.S., Sarver, D.B., Lee, S.K., Beasley, T.M., Morgan, D.E., Posey, J.A., 2014. Quantitative perfusion- and diffusion-weighted magnetic resonance imaging of gastrointestinal cancers treated with multikinase inhibitors: a pilot study. Gastrointest. Cancer Res. GCR 7, 75-81.

Krajewski, K.M., Guo, M., Van den Abbeele, A.D., Yap, J., Ramaiya, N., Jagannathan, J., Heng, D.Y.C., Atkins, M.B., McDermott, D.F., Schutz, F.A.B., Pedrosa, I., Choueiri, T.K., 2011. Comparison of four early posttherapy imaging changes (EPTIC; RECIST 1.0, tumor shrinkage, computed tomography tumor density, Choi criteria) in assessing outcome to vascular endothelial growth factor-targeted therapy in patients with advanced renal cell carcinoma. Eur. Urol. 59, 856-862. http://dx.doi.org/10.1016/j. eururo.2011.01.038.

Kreisl, T.N., Kim, L., Moore, K., Duic, P., Royce, C., Stroud, I., Garren, N., Mackey, M., Butman, J.A., Camphausen, K., Park, J., Albert, P.S., Fine, H.A., 2009. Phase II trial of single-agent bevacizumab followed by bevacizumab plus irinotecan at tumor progression in recurrent glioblastoma. J. Clin. Oncol. Off. J. Am. Soc. Clin. Oncol. 27, 740-745. http://dx. doi.org/10.1200/JCO.2008.16.3055.

Lai, X.-X., Xu, R.-A., Yu-Ping, L., Yang, H., 2016. Risk of adverse events with bevacizumab addition to therapy in advanced non-small-cell lung cancer: a meta-analysis of randomized controlled trials. OncoTargets Ther. 9, 2421-2428. http://dx.doi.org/10. 2147/OTT.S96156.

Lankheet, N.A.G., Huitema, A.D.R., Mallo, H., Adriaansz, S., Haanen, J.B.A.G., Schellens, J.H.M., Beijnen, J.H., Blank, C.U., 2013. The effect of seasonal variation and secretion of sunitinib in sweat on the development of hand-foot syndrome. Eur. J. Clin. Pharmacol. 69, 2065-2072. http://dx.doi.org/10.1007/s00228-013-1579-4.

Lankhorst, S., Kappers, M.H.W., van Esch, J.H.M., Smedts, F.M.M., Sleijfer, S., Mathijssen, R.H.J., Baelde, H.J., Danser, A.H.J., van den Meiracker, A.H., 2014. Treatment of hypertension and renal injury induced by the angiogenesis inhibitor sunitinib: preclinical study. Hypertens. Dallas Tex 1979 (64), 1282-1289. http://dx.doi.org/10. 1161/HYPERTENSIONAHA.114.04187.

Laruelle, M., Filleul, B., Duprez, T., Machiels, J.-P., 2016. Posterior reversible encephalopathy syndrome associated with sorafenib and successful retreatment. Urol. Int. http://dx.doi.org/10.1159/000443970.

Lassau, N., Chami, L., Benatsou, B., Peronneau, P., Roche, A., 2007. Dynamic contrastenhanced ultrasonography (DCE-US) with quantification of tumor perfusion: a new diagnostic tool to evaluate the early effects of antiangiogenic treatment. Eur. Radiol. 17 (Suppl. 6), F89-98.

Lassau, N., Coiffier, B., Kind, M., Vilgrain, V., Lacroix, J., Cuinet, M., Taieb, S., Aziza, R., Sarran, A., Labbe-Devilliers, C., Gallix, B., Lucidarme, O., Ptak, Y., Rocher, L., Caquot, L.M., Chagnon, S., Marion, D., Luciani, A., Feutray, S., Uzan-Augui, J., Benatsou, B., Bonastre, J., Koscielny, S., 2016. Selection of an early biomarker for vascular normalization using dynamic contrast-enhanced ultrasonography to predict outcomes of metastatic patients treated with bevacizumab. Ann. Oncol. Off. J. Eur. Soc. Med. Oncol. 27, 1922-1928. http://dx.doi.org/10.1093/annonc/mdw280.

León-Mateos, L., Mosquera, J., Antón Aparicio, L., 2015. Treatment of sunitinib-induced hypertension in solid tumor by nitric oxide donors. Redox Biol. 6, 421-425. http:// dx.doi.org/10.1016/j.redox.2015.09.007. 
Lee, J.L., Kim, M.K., Park, I., Ahn, J.-H., Lee, D.H., Ryoo, H.M., Song, C., Hong, B., Hong, J.H., Ahn, H., 2015a. RandomizEd phase II trial of Sunitinib four weeks on and two weeks off versus two weeks on and one week off in metastatic clear-cell type REnal cell carcinoma: RESTORE trial. Ann. Oncol. Off. J. Eur. Soc. Med. Oncol. 26, 2300-2305. http://dx.doi.org/10.1093/annonc/mdv357.

Lee, S.H., Hayano, K., Zhu, A.X., Sahani, D.V., Yoshida, H., 2015b. Dynamic contrastenhanced MRI kinetic parameters as prognostic biomarkers for prediction of survival of patient with advanced hepatocellular carcinoma: a pilot comparative study. Acad. Radiol. 22, 1344-1360. http://dx.doi.org/10.1016/j.acra.2015.05.012.

Lemmens, H.J.M., Ingrande, J., 2013. Pharmacology and obesity. Int. Anesthesiol. Clin. 51, 52-66. http://dx.doi.org/10.1097/AIA.0b013e31829a4d56.

Li, Y., Li, S., Zhu, Y., Liang, X., Meng, H., Chen, J., Zhang, D., Guo, H., Shi, B., 2014. Incidence and risk of sorafenib-induced hypertension: a systematic review and metaanalysis. J. Clin. Hypertens. Greenwich Conn. 16, 177-185. http://dx.doi.org/10. $1111 /$ jch. 12273.

Li, X., Abramson, R.G., Arlinghaus, L.R., Kang, H., Chakravarthy, A.B., Abramson, V.G., Farley, J., Mayer, I.A., Kelley, M.C., Meszoely, I.M., Means-Powell, J., Grau, A.M., Sanders, M., Yankeelov, T.E., 2015. Multiparametric magnetic resonance imaging for predicting pathological response after the first cycle of neoadjuvant chemotherapy in breast cancer. Invest. Radiol. 50, 195-204. http://dx.doi.org/10.1097/RLI 0000000000000100.

Liang, Z., Brooks, J., Willard, M., Liang, K., Yoon, Y., Kang, S., Shim, H., 2007. CXCR4/ CXCL12 axis promotes VEGF-mediated tumor angiogenesis through Akt signaling pathway. Biochem. Biophys. Res. Commun. 359, 716-722. http://dx.doi.org/10. 1016/j.bbrc.2007.05.182.

Lipworth, A.D., Robert, C., Zhu, A.X., 2009. Hand-foot syndrome (hand-foot skin reaction, palmar-plantar erythrodysesthesia): focus on sorafenib and sunitinib. Oncology 77, 257-271. http://dx.doi.org/10.1159/000258880.

Llovet, J.M., Ricci, S., Mazzaferro, V., Hilgard, P., Gane, E., Blanc, J.-F., de Oliveira, A.C., Santoro, A., Raoul, J.-L., Forner, A., Schwartz, M., Porta, C., Zeuzem, S., Bolondi, L., Greten, T.F., Galle, P.R., Seitz, J.-F., Borbath, I., Häussinger, D., Giannaris, T., Shan, M., Moscovici, M., Voliotis, D., Bruix, J., SHARP Investigators Study Group, 2008. Sorafenib in advanced hepatocellular carcinoma. N. Engl. J. Med. 359, 378-390. http://dx.doi.org/10.1056/NEJMoa0708857.

Lombardi, G., Zustovich, F., Farina, P., Fiduccia, P., Della Puppa, A., Polo, V., Bertorelle, R., Gardiman, M.P., Banzato, A., Ciccarino, P., Denaro, L., Zagonel, V., 2013. Hypertension as a biomarker in patients with recurrent glioblastoma treated with antiangiogenic drugs: a single-center experience and a critical review of the literature. Anticancer Drugs 24, 90-97. http://dx.doi.org/10.1097/CAD. 0b013e32835aa5fd.

Longo, R., Gasparini, G., 2007. Challenges for patient selection with VEGF inhibitors. Cancer Chemother. Pharmacol. 60, 151-170. http://dx.doi.org/10.1007/s00280006-0403-6.

Malouf, G.G., Flippot, R., Khayat, D., 2016. Therapeutic strategies for patients with metastatic renal cell carcinoma in whom first-line vascular endothelial growth factor receptor-directed therapies fail. J. Oncol. Pract. 12, 412-420. http://dx.doi.org/10 1200/JOP.2016.011809.

Marinovich, M.L., Sardanelli, F., Ciatto, S., Mamounas, E., Brennan, M., Macaskill, P., Irwig, L., von Minckwitz, G., Houssami, N., 2012. Early prediction of pathologic response to neoadjuvant therapy in breast cancer: systematic review of the accuracy of MRI. Breast Edinb. Scotl. 21, 669-677. http://dx.doi.org/10.1016/j.breast.2012.07. 006.

Marth, C., Vergote, I., Scambia, G., Oberaigner, W., Clamp, A., Berger, R., Kurzeder, C., Colombo, N., Vuylsteke, P., Lorusso, D., Hall, M., Renard, V., Pignata, S., Kristeleit, R., Altintas, S., Rustin, G., Wenham, R.M., Mirza, M.R., Fong, P.C., Oza, A., Monk, B.J., Ma, H., Vogl, F.D., Bach, B.A., 2017. ENGOT-ov-6/TRINOVA-2: randomised, double-blind, phase 3 study of pegylated liposomal doxorubicin plus trebananib or placebo in women with recurrent partially platinum-sensitive or resistant ovarian cancer. Eur. J. Cancer Oxf. Engl. 1990 (70), 111-121. http://dx.doi.org/10.1016/j. ejca.2016.09.004.

McLellan, B., Ciardiello, F., Lacouture, M.E., Segaert, S., Van Cutsem, E., 2015. Regorafenib-associated hand-foot skin reaction: practical advice on diagnosis, prevention, and management. Ann. Oncol. Off. J. Eur. Soc. Med. Oncol. 26, 2017-2026. http://dx.doi.org/10.1093/annonc/mdv244.

Messiou, C., Orton, M., Ang, J.E., Collins, D.J., Morgan, V.A., Mears, D., Castellano, I., Papadatos-Pastos, D., Brunetto, A., Tunariu, N., Mann, H., Tessier, J., Young, H., Ghiorghiu, D., Marley, S., Kaye, S.B., deBono, J.S., Leach, M.O., deSouza, N.M., 2012. Advanced solid tumors treated with cediranib: comparison of dynamic contrast-enhanced MR imaging and CT as markers of vascular activity. Radiology 265, 426-436. http://dx.doi.org/10.1148/radiol.12112565.

Miles, D.W., Chan, A., Dirix, L.Y., Cortés, J., Pivot, X., Tomczak, P., Delozier, T., Sohn, J.H., Provencher, L., Puglisi, F., Harbeck, N., Steger, G.G., Schneeweiss, A., Wardley, A.M., Chlistalla, A., Romieu, G., 2010. Phase III study of bevacizumab plus docetaxel compared with placebo plus docetaxel for the first-line treatment of human epidermal growth factor receptor 2-negative metastatic breast cancer. J. Clin. Oncol. Off. J. Am. Soc. Clin. Oncol. 28, 3239-3247. http://dx.doi.org/10.1200/JCO.2008.21. 6457.

Miller, K., Wang, M., Gralow, J., Dickler, M., Cobleigh, M., Perez, E.A., Shenkier, T., Cella, D., Davidson, N.E., 2007. Paclitaxel plus bevacizumab versus paclitaxel alone for metastatic breast cancer. N. Engl. J. Med. 357, 2666-2676. http://dx.doi.org/10. 1056/NEJMoa072113.

Mir, O., Coriat, R., Boudou-Rouquette, P., Durand, J.P., Goldwasser, F., 2012a. Sorafenibinduced diarrhea and hypophosphatemia: mechanisms and therapeutic implications. Ann. Oncol. Off. J. Eur. Soc. Med. Oncol. 23, 280-281. http://dx.doi.org/10.1093/ annonc/mdr525.

Mir, O., Coriat, R., Ropert, S., Cabanes, L., Blanchet, B., Camps, S., Billemont, B.,
Knebelmann, B., Goldwasser, F., 2012b. Treatment of bevacizumab-induced hypertension by amlodipine. Invest. New Drugs 30, 702-707. http://dx.doi.org/10. 1007/s10637-010-9549-5.

Mir, O., Brodowicz, T., Italiano, A., Wallet, J., Blay, J.-Y., Bertucci, F., Chevreau, C., Piperno-Neumann, S., Bompas, E., Salas, S., Perrin, C., Delcambre, C., LieglAtzwanger, B., Toulmonde, M., Dumont, S., Ray-Coquard, I., Clisant, S., Taieb, S., Guillemet, C., Rios, M., Collard, O., Bozec, L., Cupissol, D., Saada-Bouzid, E., Lemaignan, C., Eisterer, W., Isambert, N., Chaigneau, L., Cesne, A.L., Penel, N., 2016. Safety and efficacy of regorafenib in patients with advanced soft tissue sarcoma (REGOSARC): a randomised, double-blind, placebo-controlled, phase 2 trial. Lancet Oncol. 17, 1732-1742. http://dx.doi.org/10.1016/s1470-2045(16)30507-1.

Monk, B.J., Poveda, A., Vergote, I., Raspagliesi, F., Fujiwara, K., Bae, D.-S., Oaknin, A., Ray-Coquard, I., Provencher, D.M., Karlan, B.Y., Lhommé, C., Richardson, G., Rincón, D.G., Coleman, R.L., Marth, C., Brize, A., Fabbro, M., Redondo, A., Bamias, A., Ma, H., Vogl, F.D., Bach, B.A., Oza, A.M., 2016. Final results of a phase 3 study of trebananib plus weekly paclitaxel in recurrent ovarian cancer (TRINOVA-1): long-term survival, impact of ascites, and progression-free survival-2. Gynecol. Oncol. 143, 27-34. http://dx.doi.org/10.1016/j.ygyno.2016.07.112.

Morgan, B., Thomas, A.L., Drevs, J., Hennig, J., Buchert, M., Jivan, A., Horsfield, M.A., Mross, K., Ball, H.A., Lee, L., Mietlowski, W., Fuxuis, S., Unger, C., O'Byrne, K., Henry, A., Cherryman, G.R., Laurent, D., Dugan, M., Marmé, D., Steward, W.P., 2003. Dynamic contrast-enhanced magnetic resonance imaging as a biomarker for the pharmacological response of PTK787/ZK 222584, an inhibitor of the vascular endothelial growth factor receptor tyrosine kinases, in patients with advanced colorectal cancer and liver metastases: results from two phase I studies. J. Clin. Oncol. Off. J. Am. Soc. Clin. Oncol. 21, 3955-3964. http://dx.doi.org/10.1200/JCO.2003.08. 092.

Motzer, R.J., Hutson, T.E., Tomczak, P., Michaelson, M.D., Bukowski, R.M., Rixe, O., Oudard, S., Negrier, S., Szczylik, C., Kim, S.T., Chen, I., Bycott, P.W., Baum, C.M., Figlin, R.A., 2007. Sunitinib versus interferon alfa in metastatic renal-cell carcinoma. N. Engl. J. Med. 356, 115-124. http://dx.doi.org/10.1056/NEJMoa065044.

Motzer, R.J., Hutson, T.E., Olsen, M.R., Hudes, G.R., Burke, J.M., Edenfield, W.J., Wilding, G., Agarwal, N., Thompson, J.A., Cella, D., Bello, A., Korytowsky, B., Yuan, J., Valota, O., Martell, B., Hariharan, S., Figlin, R.A., 2012. Randomized phase II trial of sunitinib on an intermittent versus continuous dosing schedule as first-line therapy for advanced renal cell carcinoma. J. Clin. Oncol. Off. J. Am. Soc. Clin. Oncol. 30, 1371-1377. http://dx.doi.org/10.1200/JCO.2011.36.4133.

Motzer, R.J., Hutson, T.E., Cella, D., Reeves, J., Hawkins, R., Guo, J., Nathan, P., Staehler, M., de Souza, P., Merchan, J.R., Boleti, E., Fife, K., Jin, J., Jones, R., Uemura, H., De Giorgi, U., Harmenberg, U., Wang, J., Sternberg, C.N., Deen, K., McCann, L., Hackshaw, M.D., Crescenzo, R., Pandite, L.N., Choueiri, T.K., 2013. Pazopanib versus sunitinib in metastatic renal-cell carcinoma. N. Engl. J. Med. 369, 722-731. http:// dx.doi.org/10.1056/NEJMoa1303989.

Motzer, R.J., Hutson, T.E., McCann, L., Deen, K., Choueiri, T.K., 2014. Overall survival in renal-cell carcinoma with pazopanib versus sunitinib. N. Engl. J. Med. 370, 1769-1770. http://dx.doi.org/10.1056/NEJMc1400731.

Motzer, R.J., 2016. Perspective: what next for treatment? Nature 537, S111. http://dx. doi.org/10.1038/537S111a.

Murukesh, N., Dive, C., Jayson, G.C., 2010. Biomarkers of angiogenesis and their role in the development of VEGF inhibitors. Br. J. Cancer 102, 8-18. http://dx.doi.org/10. 1038/sj.bjc.6605483.

Nalluri, S.R., Chu, D., Keresztes, R., Zhu, X., Wu, S., 2008. Risk of venous thromboembolism with the angiogenesis inhibitor bevacizumab in cancer patients: a meta-analysis. JAMA 300, 2277-2285. http://dx.doi.org/10.1001/jama.2008.656.

Newsome, B.W., Ernstoff, M.S., 2008. The clinical pharmacology of therapeutic monoclonal antibodies in the treatment of malignancy; have the magic bullets arrived? $\mathrm{Br}$. J. Clin. Pharmacol. 66, 6-19. http://dx.doi.org/10.1111/j.1365-2125.2008.03187.x.

Ohtsu, A., Shah, M.A., Van Cutsem, E., Rha, S.Y., Sawaki, A., Park, S.R., Lim, H.Y., Yamada, Y., Wu, J., Langer, B., Starnawski, M., Kang, Y.-K., 2011. Bevacizumab in combination with chemotherapy as first-line therapy in advanced gastric cancer: a randomized, double-blind, placebo-controlled phase III study. J. Clin. Oncol. Off. J. Am. Soc. Clin. Oncol. 29, 3968-3976. http://dx.doi.org/10.1200/JCO.2011.36.2236.

Pécuchet, N., Lebbe, C., Mir, O., Billemont, B., Blanchet, B., Franck, N., Viguier, M., Coriat, R., Tod, M., Avril, M.-F., Goldwasser, F., 2012. Sorafenib in advanced melanoma: a critical role for pharmacokinetics? Br. J. Cancer 107, 455-461. http://dx. doi.org/10.1038/bjc.2012.287.

Pander, J., Guchelaar, H.J., Gelderblom, H., 2010. Pharmacogenetics of small-molecule tyrosine kinase inhibitors: optimizing the magic bullet. Curr. Opin. Mol. Ther. 12, 654-661.

Papadopoulos, N., Martin, J., Ruan, Q., Rafique, A., Rosconi, M.P., Shi, E., Pyles, E.A., Yancopoulos, G.D., Stahl, N., Wiegand, S.J., 2012. Binding and neutralization of vascular endothelial growth factor (VEGF) and related ligands by VEGF Trap, ranibizumab and bevacizumab. Angiogenesis 15, 171-185. http://dx.doi.org/10.1007/ s10456-011-9249-6.

Patel, T.V., Morgan, J.A., Demetri, G.D., George, S., Maki, R.G., Quigley, M., Humphreys, B.D., 2008. A preeclampsia-like syndrome characterized by reversible hypertension and proteinuria induced by the multitargeted kinase inhibitors sunitinib and sorafenib. J. Natl. Cancer Inst. 100, 282-284. http://dx.doi.org/10.1093/jnci/djm311.

Patras de Campaigno, E., Bondon-Guitton, E., Laurent, G., Montastruc, F., Montastruc, J. L., Lapeyre-Mestre, M., Despas, F., 2017. Identification of cellular targets involved in cardiac failure caused by PKI in oncology: an approach combining pharmacovigilance and pharmacodynamics. Br. J. Clin. Pharmacol. 83 (7), 1544-1555. http://dx.doi. org/10.1111/bcp.13238.

Poon, R.T., Fan, S.T., Wong, J., 2001. Clinical implications of circulating angiogenic factors in cancer patients. J. Clin. Oncol. Off. J. Am. Soc. Clin. Oncol. 19, 1207-1225. http://dx.doi.org/10.1200/jco.2001.19.4.1207. 
Porta, R., Borea, R., Coelho, A., Khan, S., Araújo, A., Reclusa, P., Franchina, T., Van Der Steen, N., Van Dam, P., Ferri, J., Sirera, R., Naing, A., Hong, D., Rolfo, C., 2017. FGFR a promising druggable target in cancer: molecular biology and new drugs. Crit. Rev. Oncol. Hematol. 113, 256-267. http://dx.doi.org/10.1016/j.critrevonc.2017.02.018.

Powles, T., Bracarda, S., Chen, M., Norry, E., Compton, N., Heise, M., Hutson, T., Harter, P., Carpenter, C., Pandite, L., Kaplowitz, N., 2015. Characterisation of liver chemistry abnormalities associated with pazopanib monotherapy: a systematic review and meta-analysis of clinical trials in advanced cancer patients. Eur. J. Cancer Oxf. Engl. 51, 1293-1302. http://dx.doi.org/10.1016/j.ejca.2015.03.019.

Presta, M., Dell'Era, P., Mitola, S., Moroni, E., Ronca, R., Rusnati, M., 2005. Fibroblast growth factor/fibroblast growth factor receptor system in angiogenesis. Cytokine Growth Factor Rev. 16, 159-178. http://dx.doi.org/10.1016/j.cytogfr.2005.01.004.

Qi, W.-X., Fu, S., Zhang, Q., Guo, X.-M., 2014a. Bevacizumab increases the risk of severe congestive heart failure in cancer patients: an up-to-date meta-analysis with a focus on different subgroups. Clin. Drug Investig. 34, 681-690. http://dx.doi.org/10.1007/ s40261-014-0222-1.

Qi, W.-X., Shen, Z., Tang, L.-N., Yao, Y., 2014b. Congestive heart failure risk in cancer patients treated with vascular endothelial growth factor tyrosine kinase inhibitors: a systematic review and meta-analysis of 36 clinical trials. Br. J. Clin. Pharmacol. 78, 748-762. http://dx.doi.org/10.1111/bcp.12387.

Reck, M., Kaiser, R., Mellemgaard, A., Douillard, J.-Y., Orlov, S., Krzakowski, M., von Pawel, J., Gottfried, M., Bondarenko, I., Liao, M., Gann, C.-N., Barrueco, J., GaschlerMarkefski, B., Novello, S., LUME-Lung 1 Study Group, 2014. Docetaxel plus nintedanib versus docetaxel plus placebo in patients with previously treated non-small-cell lung cancer (LUME-Lung 1): a phase 3, double-blind, randomised controlled trial. Lancet Oncol. 15, 143-155. http://dx.doi.org/10.1016/S1470-2045(13)70586-2.

Rini, B.I., Tamaskar, I., Shaheen, P., Salas, R., Garcia, J., Wood, L., Reddy, S., Dreicer, R., Bukowski, R.M., 2007. Hypothyroidism in patients with metastatic renal cell carcinoma treated with sunitinib. J. Natl. Cancer Inst. 99, 81-83. http://dx.doi.org/10. 1093/jnci/djk008.

Rini, B.I., Halabi, S., Rosenberg, J.E., Stadler, W.M., Vaena, D.A., Archer, L., Atkins, J.N., Picus, J., Czaykowski, P., Dutcher, J., Small, E.J., 2010. Phase III trial of bevacizumab plus interferon alfa versus interferon alfa monotherapy in patients with metastatic renal cell carcinoma: final results of CALGB 90206. J. Clin. Oncol. Off. J. Am. Soc. Clin. Oncol. 28, 2137-2143. http://dx.doi.org/10.1200/jco.2009.26.5561.

Rini, B.I., Escudier, B., Tomczak, P., Kaprin, A., Szczylik, C., Hutson, T.E., Michaelson, M.D., Gorbunova, V.A., Gore, M.E., Rusakov, I.G., Negrier, S., Ou, Y.-C., Castellano, D., Lim, H.Y., Uemura, H., Tarazi, J., Cella, D., Chen, C., Rosbrook, B., Kim, S., Motzer, R.J., 2011. Comparative effectiveness of axitinib versus sorafenib in advanced renal cell carcinoma (AXIS): a randomised phase 3 trial. Lancet Lond. Engl. 378, 1931-1939. http://dx.doi.org/10.1016/S0140-6736(11)61613-9.

Rini, B.I., Melichar, B., Ueda, T., Grünwald, V., Fishman, M.N., Arranz, J.A., Bair, A.H., Pithavala, Y.K., Andrews, G.I., Pavlov, D., Kim, S., Jonasch, E., 2013. Axitinib with or without dose titration for first-line metastatic renal-cell carcinoma: a randomised double-blind phase 2 trial. Lancet Oncol. 14, 1233-1242. http://dx.doi.org/10.1016/ S1470-2045(13)70464-9.

Robert, N.J., Diéras, V., Glaspy, J., Brufsky, A.M., Bondarenko, I., Lipatov, O.N., Perez, E.A., Yardley, D.A., Chan, S.Y.T., Zhou, X., Phan, S.-C., O'Shaughnessy, J., 2011. RIBBON-1: randomized, double-blind, placebo-controlled, phase III trial of chemotherapy with or without bevacizumab for first-line treatment of human epidermal growth factor receptor 2-negative, locally recurrent or metastatic breast cancer. J. Clin. Oncol. Off. J. Am. Soc. Clin. Oncol. 29, 1252-1260. http://dx.doi.org/10.1200/ JCO.2010.28.0982

Robinson, S.P., McIntyre, D.J.O., Checkley, D., Tessier, J.J., Howe, F.A., Griffiths, J.R., Ashton, S.E., Ryan, A.J., Blakey, D.C., Waterton, J.C., 2003. Tumour dose response to the antivascular agent ZD6126 assessed by magnetic resonance imaging. Br. J. Cancer 88, 1592-1597. http://dx.doi.org/10.1038/sj.bjc.6600926.

Rocha, A., Azevedo, I., Soares, R., 2007. Anti-angiogenic effects of imatinib target smooth muscle cells but not endothelial cells. Angiogenesis 10, 279-286. http://dx.doi.org/ 10.1007/s10456-007-9080-2.

Ronca, R., Giacomini, A., Rusnati, M., Presta, M., 2015. The potential of fibroblast growth factor/fibroblast growth factor receptor signaling as a therapeutic target in tumor angiogenesis. Expert Opin. Ther. Targets 19, 1361-1377. http://dx.doi.org/10.1517/ 14728222.2015.1062475.

Ronot, M., Bouattour, M., Wassermann, J., Bruno, O., Dreyer, C., Larroque, B., Castera, L., Vilgrain, V., Belghiti, J., Raymond, E., Faivre, S., 2014. Alternative Response Criteria (Choi, European association for the study of the liver, and modified Response Evaluation Criteria in Solid Tumors [RECIST]) Versus RECIST 1.1 in patients with advanced hepatocellular carcinoma treated with sorafenib. Oncologist 19, 394-402. http://dx.doi.org/10.1634/theoncologist.2013-0114.

Roskoski, R., 2017. Vascular endothelial growth factor (VEGF) and VEGF receptor inhibitors in the treatment of renal cell carcinomas. Pharmacol. Res. 120, 116-132. http://dx.doi.org/10.1016/j.phrs.2017.03.010.

Rossari, J.R., Metzger-Filho, O., Paesmans, M., Saini, K.S., Gennari, A., de Azambuja, E., Piccart-Gebhart, M., 2012. Bevacizumab and Breast cancer: a meta-analysis of firstline phase III studies and a critical reappraisal of available evidence. J. Oncol. 41767, 3. http://dx.doi.org/10.1155/2012/417673.

Rousseau, B., Kempf, E., Desamericq, G., Boissier, E., Chaubet-Houdu, M., Joly, C., Saldana, C., Boussion, H., Neuzillet, C., Macquin-Mavier, I., Oudard, S., Salomon, L., de la Taille, A., Tournigand, C., 2016. First-line antiangiogenics for metastatic renal cell carcinoma: a systematic review and network meta-analysis. Crit. Rev. Oncol. Hematol. 107, 44-53. http://dx.doi.org/10.1016/j.critrevonc.2016.08.012.

Rowland, A., van Dyk, M., Mangoni, A.A., Miners, J.O., McKinnon, R.A., Wiese, M.D., Rowland, A., Kichenadasse, G., Gurney, H., Sorich, M.J., 2017. Kinase inhibitor pharmacokinetics: comprehensive summary and roadmap for addressing inter-individual variability in exposure. Expert Opin. Drug Metab. Toxicol. 13, 31-49. http:// dx.doi.org/10.1080/17425255.2016.1229303.

Ruan, J., Luo, M., Wang, C., Fan, L., Yang, S.N., Cardenas, M., Geng, H., Leonard, J.P., Melnick, A., Cerchietti, L., Hajjar, K.A., 2013. Imatinib disrupts lymphoma angiogenesis by targeting vascular pericytes. Blood 121, 5192-5202. http://dx.doi.org/10 1182/blood-2013-03-490763.

Salem, J.-E., Bruguiere, E., Iserin, L., Guiochon-Mantel, A., Plouin, P.-F., 2012. Hypertension and aortorenal disease in Alagille syndrome. J. Hypertens. 30, 1300-1306. http://dx.doi.org/10.1097/HJH.0b013e3283531e1f.

Salem, J.-E., Alexandre, J., Bachelot, A., Funck-Brentano, C., 2016. Influence of steroid hormones on ventricular repolarization. Pharmacol. Ther. 167, 38-47. http://dx.doi. org/10.1016/j.pharmthera.2016.07.005.

Scagliotti, G., Novello, S., von Pawel, J., Reck, M., Pereira, J.R., Thomas, M., Abrão Miziara, J.E., Balint, B., De Marinis, F., Keller, A., Arén, O., Csollak, M., Albert, I., Barrios, C.H., Grossi, F., Krzakowski, M., Cupit, L., Cihon, F., Dimatteo, S., Hanna, N., 2010. Phase III study of carboplatin and paclitaxel alone or with sorafenib in advanced non-small-cell lung cancer. J. Clin. Oncol. Off. J. Am. Soc. Clin. Oncol. 28, 1835-1842. http://dx.doi.org/10.1200/JCO.2009.26.1321.

Scappaticci, F.A., Fehrenbacher, L., Cartwright, T., Hainsworth, J.D., Heim, W., Berlin, J., Kabbinavar, F., Novotny, W., Sarkar, S., Hurwitz, H., 2005. Surgical wound healing complications in metastatic colorectal cancer patients treated with bevacizumab. J. Surg. Oncol. 91, 173-180. http://dx.doi.org/10.1002/jso.20301.

Scartozzi, M., Faloppi, L., Svegliati Baroni, G., Loretelli, C., Piscaglia, F., Iavarone, M., Toniutto, P., Fava, G., De Minicis, S., Mandolesi, A., Bianconi, M., Giampieri, R., Granito, A., Facchetti, F., Bitetto, D., Marinelli, S., Venerandi, L., Vavassori, S., Gemini, S., D'Errico, A., Colombo, M., Bolondi, L., Bearzi, I., Benedetti, A., Cascinu, S., 2014. VEGF and VEGFR genotyping in the prediction of clinical outcome for HCC patients receiving sorafenib: the ALICE-1 study. Int. J. Cancer 135, 1247-1256. http://dx.doi.org/10.1002/ijc.28772.

Schlumberger, M., Tahara, M., Wirth, L.J., Robinson, B., Brose, M.S., Elisei, R., Habra, M.A., Newbold, K., Shah, M.H., Hoff, A.O., Gianoukakis, A.G., Kiyota, N., Taylor, M.H., Kim, S.-B., Krzyzanowska, M.K., Dutcus, C.E., de las Heras, B., Zhu, J., Sherman, S.I., 2015. Lenvatinib versus placebo in radioiodine-refractory thyroid cancer. N. Engl. J. Med. 372, 621-630. http://dx.doi.org/10.1056/NEJMoa1406470.

Schmidt, N., Hess, V., Zumbrunn, T., Rothermundt, C., Bongartz, G., Potthast, S., 2013. Choi response criteria for prediction of survival in patients with metastatic renal cell carcinoma treated with anti-angiogenic therapies. Eur. Radiol. 23, 632-639. http:// dx.doi.org/10.1007/s00330-012-2640-x.

Schneider, B.P., Wang, M., Radovich, M., Sledge, G.W., Badve, S., Thor, A., Flockhart, D.A., Hancock, B., Davidson, N., Gralow, J., Dickler, M., Perez, E.A., Cobleigh, M., Shenkier, T., Edgerton, S., Miller, K.D., 2100, E.C.O.G., 2008. Association of vascular endothelial growth factor and vascular endothelial growth factor receptor-2 genetic polymorphisms with outcome in a trial of paclitaxel compared with paclitaxel plus bevacizumab in advanced breast cancer: ECOG 2100. J. Clin. Oncol. Off. J. Am. Soc. Clin. Oncol. 26, 4672-4678. http://dx.doi.org/10.1200/JCO.2008.16.1612.

Schwartz, E.L., 2009. Antivascular actions of microtubule-binding drugs. Clin. Cancer Res. Off. J. Am. Assoc. Cancer Res. 15, 2594-2601. http://dx.doi.org/10.1158/10780432. (CCR-08-2710).

Sharma, K., Marcus, J.R., 2013. Bevacizumab and wound-healing complications: mechanisms of action, clinical evidence, and management recommendations for the plastic surgeon. Ann. Plast. Surg. 71, 434-440. http://dx.doi.org/10.1097/SAP. 0b013e31824e5e57.

Shibuya, M., 2011. Vascular endothelial growth factor (VEGF) and its receptor (VEGFR) signaling in angiogenesis: a crucial target for anti- and pro-angiogenic therapies. Genes Cancer 2, 1097-1105. http://dx.doi.org/10.1177/1947601911423031.

Sibaud, V., Lamant, L., Maisongrosse, V., Delord, J.-P., 2013. Adverse skin reactions induced by BRAF inhibitors: a systematic review. Ann. Dermatol. Venereol. 140, 510-520. http://dx.doi.org/10.1016/j.annder.2013.02.031.

Singer, S., Grommes, C., Reiner, A.S., Rosenblum, M.K., DeAngelis, L.M., 2015. Posterior reversible encephalopathy syndrome in patients with cancer. Oncologist 20, 806-811. http://dx.doi.org/10.1634/theoncologist.2014-0149.

Smidt-Hansen, T., Folkmar, T.B., Fode, K., Agerbaek, M., Donskov, F., 2013. Combination of zoledronic acid and targeted therapy is active but may induce osteonecrosis of the jaw in patients with metastatic renal cell carcinoma. J. Oral Maxillofac. Surg. Off. J. Am. Assoc. Oral Maxillofac. Surg. 71, 1532-1540. http://dx.doi.org/10.1016/j.joms. 2013.03.019.

Soria, J.-C., DeBraud, F., Bahleda, R., Adamo, B., Andre, F., Dienstmann, R., Dientsmann, R., Delmonte, A., Cereda, R., Isaacson, J., Litten, J., Allen, A., Dubois, F., Saba, C., Robert, R., D'Incalci, M., Zucchetti, M., Camboni, M.G., Tabernero, J., 2014. Phase I/ IIa study evaluating the safety, efficacy, pharmacokinetics, and pharmacodynamics of lucitanib in advanced solid tumors. Ann. Oncol. Off. J. Eur. Soc. Med. Oncol. 25, 2244-2251. http://dx.doi.org/10.1093/annonc/mdu390.

Spano, J.-P., Chodkiewicz, C., Maurel, J., Wong, R., Wasan, H., Barone, C., Létourneau, R., Bajetta, E., Pithavala, Y., Bycott, P., Trask, P., Liau, K., Ricart, A.D., Kim, S., Rixe, O., 2008. Efficacy of gemcitabine plus axitinib compared with gemcitabine alone in patients with advanced pancreatic cancer: an open-label randomised phase II study. Lancet 371, 2101-2108. http://dx.doi.org/10.1016/s0140-6736(08)60661-3.

Spano, J.-P., Moore, M.J., Pithavala, Y.K., Ricart, A.D., Kim, S., Rixe, O., 2012. Phase I study of axitinib (AG-013736) in combination with gemcitabine in patients with advanced pancreatic cancer. Invest. New Drugs 30, 1531-1539. http://dx.doi.org/ 10.1007/s10637-011-9697-2.

Stacchiotti, S., Collini, P., Messina, A., Morosi, C., Barisella, M., Bertulli, R., Piovesan, C., Dileo, P., Torri, V., Gronchi, A., Casali, P.G., 2009. High-grade soft-tissue sarcomas: tumor response assessment-pilot study to assess the correlation between radiologic and pathologic response by using RECIST and Choi criteria. Radiology 251, 447-456. http://dx.doi.org/10.1148/radiol.2512081403.

Stein, M.N., Flaherty, K.T., 2007. CCR drug updates: sorafenib and sunitinib in renal cell 
carcinoma. Clin. Cancer Res. Off. J. Am. Assoc. Cancer Res. 13, 3765-3770. http:// dx.doi.org/10.1158/1078-0432. (CCR-06-2844).

Strumberg, D., Awada, A., Hirte, H., Clark, J.W., Seeber, S., Piccart, P., Hofstra, E., Voliotis, D., Christensen, O., Brueckner, A., Schwartz, B., 2006. Pooled safety analysis of BAY 43-9006 (sorafenib) monotherapy in patients with advanced solid tumours: is rash associated with treatment outcome? Eur. J. Cancer Oxf. Engl. 1990 42, 548-556. http://dx.doi.org/10.1016/j.ejca.2005.11.014.

Tabernero, J., Yoshino, T., Cohn, A.L., Obermannova, R., Bodoky, G., Garcia-Carbonero, R., Ciuleanu, T.-E., Portnoy, D.C., Van Cutsem, E., Grothey, A., Prausová, J., GarciaAlfonso, P., Yamazaki, K., Clingan, P.R., Lonardi, S., Kim, T.W., Simms, L., Chang, S.C., Nasroulah, F., RAISE Study Investigators, 2015. Ramucirumab versus placebo in combination with second-line FOLFIRI in patients with metastatic colorectal carcinoma that progressed during or after first-line therapy with bevacizumab, oxaliplatin, and a fluoropyrimidine (RAISE): a randomised, double-blind, multicentre, phase 3 study. Lancet Oncol. 16, 499-508. http://dx.doi.org/10.1016/S1470-2045(15) 70127-0.

Tan, A.R., Gibbon, D.G., Stein, M.N., Lindquist, D., Edenfield, J.W., Martin, J.C., Gregory, C., Suttle, A.B., Tada, H., Botbyl, J., Stephenson, J.J., 2013. Effects of ketoconazole and esomeprazole on the pharmacokinetics of pazopanib in patients with solid tumors. Cancer Chemother. Pharmacol. 71, 1635-1643. http://dx.doi.org/10.1007/ s00280-013-2164-3.

Taphoorn, M.J.B., Henriksson, R., Bottomley, A., Cloughesy, T., Wick, W., Mason, W.P., Saran, F., Nishikawa, R., Hilton, M., Theodore-Oklota, C., Ravelo, A., Chinot, O.L., 2015. Health-related quality of life in a randomized phase III study of bevacizumab, temozolomide, and radiotherapy in newly diagnosed glioblastoma. J. Clin. Oncol. Off. J. Am. Soc. Clin. Oncol. 33, 2166-2175. http://dx.doi.org/10.1200/JCO.2014. 60.3217.

Thai, H.-T., Veyrat-Follet, C., Mentré, F., Comets, E., 2013. Population pharmacokinetic analysis of free and bound aflibercept in patients with advanced solid tumors. Cancer Chemother. Pharmacol. 72, 167-180. http://dx.doi.org/10.1007/s00280-0132182-1.

Tofts, P.S., Brix, G., Buckley, D.L., Evelhoch, J.L., Henderson, E., Knopp, M.V., Larsson, H.B., Lee, T.Y., Mayr, N.A., Parker, G.J., Port, R.E., Taylor, J., Weisskoff, R.M., 1999 Estimating kinetic parameters from dynamic contrast-enhanced T(1)-weighted MRI of a diffusable tracer: standardized quantities and symbols. J. Magn. Reson. Imaging JMRI 10, 223-232.

Tofts, P.S., 1997. Modeling tracer kinetics in dynamic Gd-DTPA MR imaging. J. Magn. Reson. Imaging JMRI 7, 91-101.

Uitdehaag, J.C.M., Verkaar, F., Alwan, H., de Man, J., Buijsman, R.C., Zaman, G.J.R. 2012. A guide to picking the most selective kinase inhibitor tool compounds for pharmacological validation of drug targets. Br. J. Pharmacol. 166, 858-876. http:// dx.doi.org/10.1111/j.1476-5381.2012.01859.x.

Urban, C., Anadkat, M.J., 2013. A review of cutaneous toxicities from targeted therapies in the treatment of colorectal cancers. J. Gastrointest. Oncol. 4, 319-327. http://dx. doi.org/10.3978/j.issn.2078-6891.2013.033.

Van Cutsem, E., Vervenne, W.L., Bennouna, J., Humblet, Y., Gill, S., Van Laethem, J.-L., Verslype, C., Scheithauer, W., Shang, A., Cosaert, J., Moore, M.J., 2009. Phase III trial of bevacizumab in combination with gemcitabine and erlotinib in patients with metastatic pancreatic cancer. J. Clin. Oncol. Off. J. Am. Soc. Clin. Oncol. 27, 2231-2237. http://dx.doi.org/10.1200/jco.2008.20.0238.

Van Cutsem, E., Tabernero, J., Lakomy, R., Prenen, H., Prausová, J., Macarulla, T., Ruff, P., van Hazel, G.A., Moiseyenko, V., Ferry, D., McKendrick, J., Polikoff, J., Tellier, A., Castan, R., Allegra, C., 2012. Addition of aflibercept to fluorouracil, leucovorin, and irinotecan improves survival in a phase III randomized trial in patients with metastatic colorectal cancer previously treated with an oxaliplatin-based regimen. J. Clin. Oncol. Off. J. Am. Soc. Clin. Oncol. 30, 3499-3506. http://dx.doi.org/10.1200/jco. 2012.42.8201.

van Kinschot, C.M.J., van Erp, N.P., Feberwee, T., Dezentjé, V.O., 2015. Sunitinib treatment in a patient with metastatic renal cell carcinoma and bariatric surgery. Eur. J. Clin. Pharmacol. 71, 1279-1281. http://dx.doi.org/10.1007/s00228-015-1902-3.

Varey, A.H.R., Rennel, E.S., Qiu, Y., Bevan, H.S., Perrin, R.M., Raffy, S., Dixon, A.R., Paraskeva, C., Zaccheo, O., Hassan, A.B., Harper, S.J., Bates, D.O., 2008. VEGF165b, an antiangiogenic VEGF-A isoform, binds and inhibits bevacizumab treatment in experimental colorectal carcinoma: balance of pro- and antiangiogenic VEGF-A isoforms has implications for therapy. Br. J. Cancer 98, 1366-1379. http://dx.doi.org/ $10.1038 /$ sj.bjc. 6604308

Veldt, A.A.M., van der Meijerink, M.R., Eertwegh, A.J.M., van den Haanen, J.B.A.G. Boven, E., 2010. Choi response criteria for early prediction of clinical outcome in patients with metastatic renal cell cancer treated with sunitinib. Br. J. Cancer 102,
803-809. http://dx doi.org/10.1038/sj.bjc.6605567.

Vempati, P., Popel, A.S., Mac Gabhann, F., 2014. Extracellular regulation of VEGF: isoforms, proteolysis, and vascular patterning. Cytokine Growth Factor Rev. 25, 1-19. http://dx.doi.org/10.1016/j.cytogfr.2013.11.002.

Verheijen, R.B., Bins, S., Mathijssen, R.H.J., Lolkema, M.P., van Doorn, L., Schellens, J.H.M., Beijnen, J.H., Langenberg, M.H.G., Huitema, A.D.R., Steeghs, N., Dutch Pharmacology Oncology Group, 2016. Individualized pazopanib dosing: a prospective feasibility study in cancer patients. Clin. Cancer Res. Off. J. Am. Assoc. Cancer Res. 22, 5738-5746. http://dx.doi.org/10.1158/1078-0432. (CCR-16-1255).

von Minckwitz, G., Eidtmann, H., Rezai, M., Fasching, P.A., Tesch, H., Eggemann, H., Schrader, I., Kittel, K., Hanusch, C., Kreienberg, R., Solbach, C., Gerber, B., Jackisch, C., Kunz, G., Blohmer, J.-U., Huober, J., Hauschild, M., Fehm, T., Müller, B.M., Denkert, C., Loibl, S., Nekljudova, V., Untch, M., German Breast Group, Arbeitsgemeinschaft Gynäkologische Onkologie-Breast Study Groups, 2012. Neoadjuvant chemotherapy and bevacizumab for HER2-negative breast cancer. $\mathrm{N}$. Engl. J. Med. 366, 299-309. http://dx.doi.org/10.1056/NEJMoa1111065.

Vrdoljak, E., Rini, B., Schmidinger, M., Omrčen, T., Torday, L., Szczylik, C., Sella, A., 2013. Bisphosphonates and vascular endothelial growth factor-targeted drugs in the treatment of patients with renal cell carcinoma metastatic to bone. Anticancer Drugs 24, 431-440. http://dx.doi.org/10.1097/cad.0b013e328360335f.

Vredenburgh, J.J., Desjardins, A., Herndon, J.E., Marcello, J., Reardon, D.A., Quinn, J.A. Rich, J.N., Sathornsumetee, S., Gururangan, S., Sampson, J., Wagner, M., Bailey, L., Bigner, D.D., Friedman, A.H., Friedman, H.S., 2007. Bevacizumab plus irinotecan in recurrent glioblastoma multiforme. J. Clin. Oncol. Off. J. Am. Soc. Clin. Oncol. 25, 4722-4729. http://dx.doi.org/10.1200/JCO.2007.12.2440.

Wade, R., Duarte, A., Simmonds, M., Rodriguez-Lopez, R., Duffy, S., Woolacott, N., Spackman, E., 2015. The clinical and cost effectiveness of aflibercept in combination with irinotecan and fluorouracil-based therapy (FOLFIRI) for the treatment of metastatic colorectal cancer which has progressed following prior oxaliplatin-Based chemotherapy: a critique of the evidence. PharmacoEconomics 33, 457-466. http:// dx.doi.org/10.1007/s40273-015-0257-z.

Wells, S.A., Robinson, B.G., Gagel, R.F., Dralle, H., Fagin, J.A., Santoro, M., Baudin, E., Elisei, R., Jarzab, B., Vasselli, J.R., Read, J., Langmuir, P., Ryan, A.J., Schlumberger, M.J., 2012. Vandetanib in patients with locally advanced or metastatic medullary thyroid cancer: a randomized, double-blind phase III trial. J. Clin. Oncol. Off. J. Am. Soc. Clin. Oncol. 30, 134-141. http://dx.doi.org/10.1200/jco.2011.35.5040.

Wolter, P., Stefan, C., Decallonne, B., Dumez, H., Bex, M., Carmeliet, P., Schöffski, P., 2008. The clinical implications of sunitinib-induced hypothyroidism: a prospective evaluation. Br. J. Cancer 99, 448-454. http://dx.doi.org/10.1038/sj.bjc.6604497.

Wu, Y.S., Shui, L., Shen, D., Chen, X., 2017. Bevacizumab combined with chemotherapy for ovarian cancer: an updated systematic review and meta-analysis of randomized controlled trials. Oncotarget 8, 10703-10713. http://dx.doi.org/10.18632/ oncotarget.12926.

Xu, C.F., Xue, Z., Bing, N., King, K.S., McCann, L.A., de Souza, P.L., Goodman, V.L., Spraggs, C.F., Mooser, V.E., Pandite, L.N., 2012. Concomitant use of pazopanib and simvastatin increases the risk of transaminase elevations in patients with cancer. Ann. Oncol. Off. J. Eur. Soc. Med. Oncol. 23, 2470-2471. http://dx.doi.org/10.1093/ annonc/mds249.

Yu, H., van Erp, N., Bins, S., Mathijssen, R.H.J., Schellens, J.H.M., Beijnen, J.H., Steeghs, N., Huitema, A.D.R., 2017. Development of a pharmacokinetic model to describe the complex pharmacokinetics of pazopanib in cancer patients. Clin. Pharmacokinet. 56, 293-303. http://dx.doi.org/10.1007/s40262-016-0443-y.

Zamorano, J.L., Lancellotti, P., Rodriguez Muñoz, D., Aboyans, V., Asteggiano, R., Galderisi, M., Habib, G., Lenihan, D.J., Lip, G.Y.H., Lyon, A.R., Lopez Fernandez, T., Mohty, D., Piepoli, M.F., Tamargo, J., Torbicki, A., Suter, T.M., 2016. Authors/Task Force Members, ESC Committee for Practice Guidelines (CPG):, 2016.ESC Position Paper on cancer treatments and cardiovascular toxicity developed under the auspices of the ESC Committee for Practice Guidelines: the Task Force for cancer treatments and cardiovascular toxicity of the European Society of Cardiology (ESC). Eur. Heart J. 37, 2768-2801. http://dx.doi.org/10.1093/eurheartj/ehw211.

Zhu, X., Wu, S., Dahut, W.L., Parikh, C.R., 2007. Risks of proteinuria and hypertension with bevacizumab, an antibody against vascular endothelial growth factor: systematic review and meta-analysis. Am. J. Kidney Dis. Off. J. Natl. Kidney Found 49, 186-193. http://dx.doi.org/10.1053/j.ajkd.2006.11.039.

Zhu, X., Tian, X., Yu, C., Hong, J., Fang, J., Chen, H., 2016. Increased risk of hemorrhage in metastatic colorectal cancer patients treated with bevacizumab: an updated metaanalysis of 12 randomized controlled trials. Medicine (Baltimore) 95, e4232. http:// dx.doi.org/10.1097/md.0000000000004232. 